\title{
Photochemical processing of organic aerosol at nearby continental sites: contrast between urban plumes and regional aerosol
}

\author{
J. G. Slowik ${ }^{1,3, *}$, J. Brook ${ }^{4}$, R. Y.-W. Chang ${ }^{1,3}$, G. J. Evans ${ }^{2,3}$, K. Hayden ${ }^{4}$, C.-H. Jeong ${ }^{4}$, S.-M. Li ${ }^{4}$, J. Liggio ${ }^{4}$, \\ P. S. K. Liu ${ }^{4}$, M. McGuire ${ }^{2,3}$, C. Mihele ${ }^{4}$, S. Sjostedt ${ }^{1,3,4}$, A. Vlasenko ${ }^{1,3,4}$, and J. P. D. Abbatt ${ }^{1,2}$ \\ ${ }^{1}$ Department of Chemistry, University of Toronto, Toronto, Canada \\ ${ }^{2}$ Department of Chemical Engineering and Applied Chemistry, University of Toronto, Toronto, Canada \\ ${ }^{3}$ Southern Ontario Centre for Atmospheric Aerosol Research, University of Toronto, Toronto, Canada \\ ${ }^{4}$ Science and Technology Branch, Environment Canada, Toronto, Canada \\ *now at: Paul Scherrer Institut, 5232 Villigen PSI, Switzerland
}

Received: 15 September 2010 - Published in Atmos. Chem. Phys. Discuss.: 26 October 2010

Revised: 4 March 2011 - Accepted: 16 March 2011 - Published: 31 March 2011

\begin{abstract}
As part of the BAQS-Met 2007 field campaign, Aerodyne time-of-flight aerosol mass spectrometers (ToFAMS) were deployed at two sites in southwestern Ontario from 17 June to 11 July 2007. One instrument was located at Harrow, ON, a rural, agriculture-dominated area approximately $40 \mathrm{~km}$ southeast of the Detroit/Windsor/Windsor urban area and $5 \mathrm{~km}$ north of Lake Erie. The second instrument was located at Bear Creek, ON, a rural site approximately $70 \mathrm{~km}$ northeast of the Harrow site and $50 \mathrm{~km}$ east of Detroit/Windsor. Positive matrix factorization analysis of the combined organic mass spectral dataset yields factors related to secondary organic aerosol (SOA), direct emissions, and a factor tentatively attributed to the reactive uptake of isoprene and/or condensation of its early generation reaction products. This is the first application of PMF to simultaneous AMS measurements at different sites, an approach which allows for self-consistent, direct comparison of the datasets. Case studies are utilized to investigate processing of SOA from (1) fresh emissions from Detroit/Windsor and (2) regional aerosol during periods of inter-site flow. A strong correlation is observed between SOA/excess $\mathrm{CO}$ and photochemical age as represented by the $\mathrm{NO}_{\mathrm{x}} / \mathrm{NO}_{\mathrm{y}}$ ratio for Detroit/Windsor outflow. Although this correlation is not evident for more aged air, measurements at the two sites during inter-site transport nevertheless show evidence of continued atmospheric processing by SOA production. However, the rate of SOA production decreases with airmass age from an
\end{abstract}

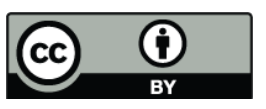

Correspondence to: J. P. D. Abbatt (jabbatt@chem.utoronto.ca) initial value of $\sim 10.1 \mu \mathrm{g} \mathrm{m}^{-3} \mathrm{ppmv}_{\mathrm{CO}}^{-1} \mathrm{~h}^{-1}$ for the first $\sim 10 \mathrm{~h}$ of plume processing to near-zero in an aged airmass (i.e. after several days). The initial SOA production rate is comparable to the observed rate in Mexico City over similar timescales.

\section{Introduction}

Quantification of aerosol effects on climate (Albrecht et al., 1989; Twomey et al., 1984), visibility (Eidels-Dubovoi, 2002; Pryor et al., 1997), and health (Pope et al., 2006; Gamble, 1998; Peters et al., 1997) is complicated by uncertainties in particle sources and atmospheric transformations. In particular, major uncertainties have been demonstrated in the formation and evolution of secondary organic aerosol (SOA) in polluted regions (Volkamer et al., 2006). Recently, significant advances have been made in identifying the role of gas/particle partitioning in SOA formation (Robinson et al., 2007). Inclusion of these processes in SOA models has improved the agreement between modelled and measured SOA mass in polluted regions; however, discrepancies remain between modelled and measured particle properties (e.g. composition, volatility) (Dzepina et al., 2009). There is a continuing need for direct ambient measurements for characterization and improved prediction of particle aging.

Studies of the atmospheric processing of aerosol have previously been conducted using methods such as mobile sampling platforms (e.g. Jimenez et al., 2009), multiple stationary sites (e.g. Takegawa et al., 2006), and fixed or mobile sites at which photochemical age is estimated utilizing the ratios of reactive hydrocarbons (e.g. Herndon et al., 2008;

Published by Copernicus Publications on behalf of the European Geosciences Union. 
Roberts et al., 1984) or nitrogen-containing species (e.g. Kleinman et al., 2008; Takegawa et al., 2006). Organic aerosol (OA) mass in Tokyo outflow was observed to increase by a factor of 4 to 5 within 8 to $16 \mathrm{~h}$ of emission using ground site measurements north of the city (Takegawa et al., 2006). Aircraft measurements in the Mexico City urban plume showed a factor of 7 increase in OA within $\sim 35 \mathrm{~km}$ of the source region (Kleinman et al., 2008). Observations in the anthropogenically-influenced eastern United States show source-to-receptor increases in OA on the order of a factor of 3 to 10 (Kleinman et al., 2007; Weber et al., 2007; Sullivan et al., 2006).

The present study investigates aerosol processing from comparison of OA composition measurements by time-offlight aerosol mass spectrometers (ToF-AMS) at two locations in southwestern Ontario, Canada, during the 2007 BAQSMET (Border Air Quality Study-Meteorology) field campaign. OA composition is described using the Positive Matrix Factorization (PMF) factor analysis technique (Paatero et al., 1994). Such analysis has been previously conducted on numerous AMS datasets (see for example Morgan et al., 2010; $\mathrm{Ng}$ et al., 2010; Slowik et al., 2010; Ulbrich et al., 2009; Lanz et al., 2007), typically resulting in a description of the SOA component as a linear combination of two oxygenated organic aerosol (OOA) factors: a more oxygenated, less volatile factor ("OOA-1") and a less oxygenated, more volatile factor sometimes associated with fresher aerosol ("OOA-2"). Aircraft measurements over Europe indicate an increase in the OOA-1/organics from $\sim 60 \%$ near-source to $>80 \%$ (regional background) (Morgan et al., $2010)$, with airmass age estimated from gas ratios $\left(\mathrm{O}_{3} / \mathrm{NO}_{\mathrm{x}}\right)$. This is qualitatively consistent with aircraft measurements in the Mexico City outflow showing an initial increase in the OOA- 1 and OOA- 2 fractions in the first $\sim 3 \mathrm{~h}$, with only the OOA-1 fraction increasing from $\sim 3$ to $\sim 6 \mathrm{~h}$ (Jimenez et al., 2009), where the airmass age is estimated from meteorological factors and sampling locations. In the present study, atmospheric processing of OA is evaluated using both estimates of photochemical age from the $\mathrm{NO}_{\mathrm{x}} / \mathrm{NO}_{\mathrm{y}}$ ratio and periods of flow between stationary ground sites.

A central goal of the BAQSMET campaign was to identify the sources and processes governing aerosol composition in southern Ontario. Such processes include atmospheric aging of both (1) plumes from nearby emissions sources and (2) regional aerosol. The literature contains many studies investigating processing in urban or industrial outflow, as well as biomass burning plumes (e.g. Jimenez et al., 2009; Capes et al., 2008; de Gouw et al., 2008; Kleinman et al., 2008; Weber et al., 2007; Takegawa et al., 2006). However, semi-Langrangian-type studies of the processing of regional aerosol, not significantly impacted by recent urban emissions, have not been extensively performed. Nonetheless, there is a general need to understand the timescales and characteristics of such aging in order to constrain the possible mechanisms and quantities of SOA that can be formed under different conditions. The present study provides an opportunity for measurement of regional aerosol processing and for comparison of such aging with that in urban outflow. Aerosol mass spectra are analyzed using positive matrix factorization (PMF) to assess changes in organic aerosol composition during atmospheric processing. For direct comparison of measurements collected simultaneously by different instruments at different sites, all measurements are combined into a single dataset for PMF analysis. This combined approach is necessary to ensure consistency in inter-site comparisons; otherwise, differences in the set of factor profiles obtained may bias comparisons. To our knowledge, this is the first application of PMF to such a dataset, although previous studies have applied PMF to mass spectral datasets collected from mobile sampling platforms.

\section{Materials and methods}

\subsection{Sampling and instrumentation}

Sampling for the BAQSMET field campaign was conducted from 20 June to 11 July 2007, from a number of stationary and mobile platforms in southwest Ontario. The data presented in this manuscript were obtained at two stationary ground sites: Harrow and Bear Creek. The locations of the sites and the region of study are shown in other BAQSMET special issue publications such as Levy et al. (2010) and in Fig. S1. Sampling at the Harrow site $\left(42.03^{\circ} \mathrm{N}\right.$, $82.90^{\circ} \mathrm{W}$ ) was performed from the MAPLE mobile laboratory (Mobile Analysis of ParticuLate in the Environment), deployed at an Agriculture Canada research station. This rural site is surrounded by farmland, and is located $\sim 5 \mathrm{~km}$ north of Lake Erie and $\sim 30 \mathrm{~km}$ south/southwest of the Detroit/Windsor metropolitan area. The Detroit/Windsor area is a major transportation hub and includes numerous industrial emissions sources such as automobile manufacturers, steel-making plants, petrochemical refineries, and coal fired power plants. In addition to outflow from Detroit/Windsor, the site is frequently influenced by industrial emissions from the Ohio River Valley and the midwest US, which are transported to the site from varying distances, including flow across Lake Erie. The Bear Creek site $\left(42.51^{\circ} \mathrm{N}, 82.34^{\circ} \mathrm{W}\right)$ is located in a small wetlands area surrounded by farmland, approximately $60 \mathrm{~km}$ northwest of Harrow. Immediately west and southwest of the site is Lake St. Clair and the Detroit/Windsor area is on the opposite shore. The region between the Harrow and Bear Creek sites consists mostly of farmland. An airmass moving between the two sites would not be expected to encounter major emissions sources, with the possible exception of a major highway perpendicular to the Harrow-Bear Creek transect and approximately halfway between the sites.

Particle composition at both sites was measured by Aerodyne time-of-flight aerosol mass spectrometers (ToF-AMS, 
Aerodyne Research, Inc., Billerica, MA, USA). A unit mass resolution instrument (C-ToF-AMS) was deployed at Harrow (17 June to 10 July) and a high-resolution instrument (HRToF-AMS) was deployed at Bear Creek (28 June to 10 July). The AMS provides quantitative size-resolved mass spectra of the non-refractory component of submicron aerosol, where non-refractory is defined as material that vaporizes at $\sim 600^{\circ} \mathrm{C}$ and $\sim 10^{-7}$ torr. Instrument operating principles, calibration procedures, and analysis protocols are described in detail in the literature (e.g. Canagaratna et al., 2007; DeCarlo et al., 2006; Drewnick et al., 2005; Allan et al., 2003; Jayne et al., 2000). An important parameter in determining quantitative mass concentrations from AMS data is the bounce collection efficiency, defined as the fraction of particles impacting the vaporizer that actually vaporize and yield a mass spectrum. For the Harrow AMS, this parameter was calculated for particles larger than $\sim 215 \mathrm{~nm}$ by comparison of single particle mass spectra with light scattering pulses provided by an optical scattering module (Cross et al., 2009). The collection efficiency was estimated as the fraction of optically-detected particles yielding single particle mass spectra above background levels, and this ratio was assumed to apply across the entire detectable size range of the AMS. Generally, the collection efficiency was estimated at $\sim 0.6$, consistent with estimates obtained during the previous month (Slowik et al., 2010). However, during some periods values as high as $\sim 1$ were observed. These increased values correspond with increased aerosol water content, and are believed to be due to temperature gradients between outdoor air and the sampling enclosure. The Bear Creek AMS did not have an optical scattering module, and collection efficiency was estimated at 0.57 by comparison of AMS and scanning mobility particle sizer (SMPS) (TSI, Inc., St. Paul, MN, USA) measurements using the method described in Slowik et al. (2010).

The AMS particle composition measurements are discussed in conjunction with measurements by several other instruments. Volatile organic compounds (VOCs) were measured only at the Harrow site by a Proton Transfer ReactionMass Spectrometer (PTR-MS) (Lindinger et al., 1998; de Gouw and Warneke, 2007). In the PTR-MS, trace gases are ionized by $\mathrm{H}_{3} \mathrm{O}^{+}$ions generated by a cathode discharge in water vapor and detected using quadrupole mass spectrometry. Details of instrument operation, calibration, and performance during BAQS-Met are discussed by Sjostedt et al. (2010). Measurements of $\mathrm{NO}_{\mathrm{x}}$ and $\mathrm{CO}$ were performed at both sites. Measurements of $\mathrm{NO}, \mathrm{NO}_{2}$, and $\mathrm{NO}_{\mathrm{y}}$ (sum of all nitrogen oxides) were measured using a TECO $42 \mathrm{C}$ analyzer (Thermo Electron Corporation, Waltham, MA, USA), which selectively converts nitrogen oxide species to NO and detects them by chemiluminescence. Instrument operation and performance during BAQSMET are discussed elsewhere (Markovic et al., 2010). CO was measured using a TECO 48C infrared spectrophotometer (Thermo Electron Corporation, Waltham, MA, USA).

\subsection{Back trajectories}

Back trajectories are utilized to identify potential particle sources and periods transport between sampling locations. In the present study, we discuss (1) back trajectories calculated using the NOAA HYSPLIT model (Draxler and Rolph, 2010; Rolph, 2010) and (2) back trajectories calculated using higher temporal and spatial resolution by a model developed by the Canadian Meteorological Centre (CMC) (D'Amours and Pagé, 2001). The CMC high-resolution trajectory model calculates air parcel back trajectories in 2-min sequential increments, arriving $500 \mathrm{~m}$ a.g.l. at the Harrow site. Trajectories are calculated with the GEM-LAM (Global Environment Multiscale-Local Area Model) model using a $2.5 \mathrm{~km}$ resolution grid with 58 vertical levels. Model domain for the BAQS-Met campaign covers the area bounded by latitude 39.5 to $46.6^{\circ}$ and longitude -77.7 to $86.5^{\circ}$.

\subsection{Positive matrix factorization (PMF)}

The organic mass spectra from the AMS instruments at the Harrow (C-ToF-AMS) and Bear Creek (HR-ToF-AMS) are analyzed by positive matrix factorization (PMF). PMF is a statistical technique in which the organic mass spectral time series $(\mathbf{X})$, is represented as a linear combination of a set of characteristic factor profiles $(\mathbf{F})$ and their time-dependent intensities (G) (Paatero et al., 1994; Paatero, 1997). PMF is thus described by the matrix equation $\mathbf{X}=\mathbf{G F}+\mathbf{E}$, where $\mathbf{E}$ is the residual matrix, defined as the difference between the data matrix $(\mathbf{X})$ and the fitted solution $(\mathbf{G F})$. To permit direct comparison of factor mass loadings obtained at Harrow and Bear Creek, data from the two sites are combined into a single $\mathbf{X}$ matrix such that each row contains a complete mass spectrum from either Harrow or Bear Creek, and the total number of rows (6224) equals the total number of spectra acquired at Harrow (5389) plus the number at Bear Creek (835). The same structure applies to the associated uncertainty matrix $\mathbf{S}$. HR-ToF-AMS data were reduced to unit mass resolution for this analysis. The PMF analysis was conducted using the PMF2 software package version 4.2 (P. Paatero, U. of Helsinki, Finland) in the robust mode, together with the CU AMS PMF Tool (Ulbrich et al., 2009).

Uncertainties for the AMS data are calculated as discussed in the literature (Allan et al., 2003). Briefly, the uncertainties are a convolution of a Poisson distribution representing ion counting statistics and a detector-dependent Gaussian distribution representing the variation in signal obtained for a single ion. Uncertainties are calculated independently for the background (i.e. blocked particle beam) and ambient (unblocked beam) signals and summed in quadrature, yielding the expression $\Delta I_{\mathrm{d}}=\alpha \frac{\sqrt{I_{\mathrm{o}}+I_{\mathrm{b}}}}{\sqrt{t_{\mathrm{s}}}}$. Here $I_{\mathrm{o}}$ and $I_{\mathrm{b}}$ are the ion signals in the unblocked and blocked (background) positions, $t_{\mathrm{s}}$ is the sampling time, and $\alpha$ is a factor accounting for the width of the Gaussian ion signal distribution. A minimum error of 1 ion was applied throughout the $\mathbf{S}$ matrix, 
and the organic peaks calculated as a fraction of the $\mathrm{CO}_{2}^{+}$ ion $(m / z 44,18,17$, and 16) were downweighted as described elsewhere (Ulbrich et al., 2009). Matrix rotations were explored by varying the $f$ Peak parameter from -2.0 to 2.0. As discussed in Sect. 3.1, the selected solution was obtained at $f$ Peak $=0.5$. The solution was initiated from 100 random starting points ("seeds") at $f$ Peak $=0.5$; all convergent solutions were found to be consistent with the presented solution, which was obtained at seed $=1$.

\section{Results and discussion}

\subsection{Organic spectral analysis}

As discussed in Sect. 2.2, the organic mass spectra from both AMS instruments were analyzed utilizing PMF. As noted above, this approach simplifies interpretation of the PMF results by ensuring consistency in the OA factors obtained at the two sites. A 4-factor solution was selected as the best representation of the data. Three of the four factors obtained (hydrocarbon-like organic aerosol, "HOA"; oxygenated organic aerosol, type 1 and 2, "OOA-1" and "OOA-2," where OOA-1 is the more oxygenated and less volatile) are similar to those obtained in previous PMF analyses of AMS data (e.g. Slowik et al., 2010; Ulbrich et al., 2009; Lanz et al., 2007). OOA-1 and OOA-2 have recently been identified with volatility, with OOA-1 denoted as "low-volatility OOA" (LV-OOA) and OOA-2 denoted as "semivolatile OOA" (SVOOA) (Jimenez et al., 2009). Because the BAQS-Met data do not provide a means for evaluating volatility, the more general OOA-1 and OOA-2 terms are used here. The 4th factor ("UNKN") is hypothesized to result from the reactive uptake of biogenic VOCs onto fresh sulfate aerosol (Stroud et al., 2010) and/or condensation of early-generation isoprene oxidation products. A brief summary of the mass spectral and temporal characteristics of the factors is provided below. Solutions with additional factors were explored but could not be successfully interpreted. The 5-factor solution yielded 2 HOA-like factors with strongly correlated mass spectra and time series. The 6-factor solution represented OOA-like aerosol with 3 factors rather than 2 . While we cannot rule out the possibility that these higher-order solutions contain real information, they cannot be meaningfully interpreted in the present study and the 4-factor solution is discussed below.

The selected solution was obtained at $f$ Peak $=0.5$. This solution represents the minimum $Q$-value for a 4 -factor solution, although it is very similar to that obtained at $f$ Peak $=0$ ( $0.1 \%$ difference). These nearly identical $Q$-values indicate that the solutions are of similar goodness of fit. However, at $f$ Peak $=0$ the OOA- 1 and OOA-2 spectra are too similar to each other to be distinguished reliably. On the other hand, the OOA-1 and OOA-2 spectra are significantly different at $f$ Peak $=0.5$. (For example, a characteristic difference between OOA-1 and OOA-2 spectra observed in many

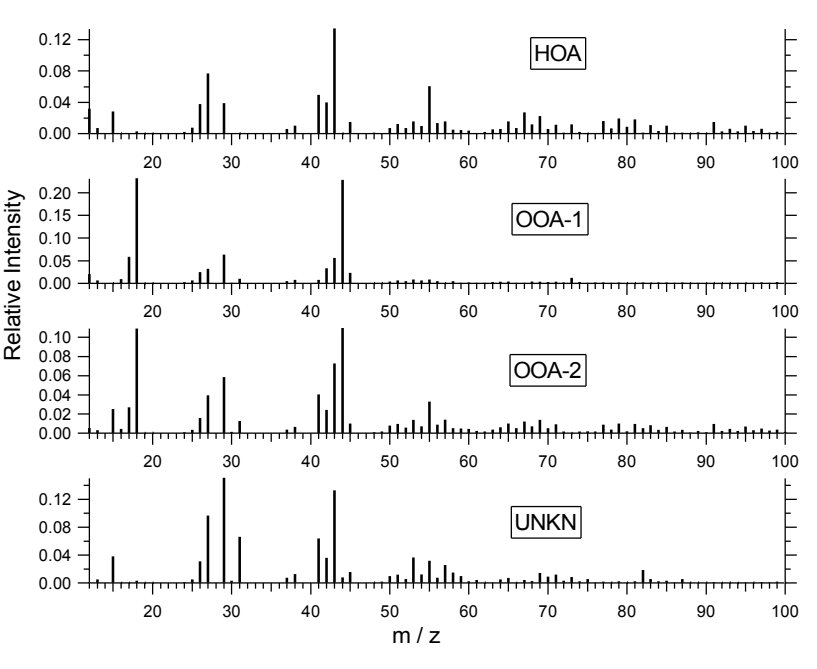

Fig. 1. Factor mass spectra for the 4-factor PMF solution to the combined Harrow/Bear Creek dataset obtained at $f$ Peak $=0.5$. Factor mass spectra are normalized such that each spectrum sums to 1 across all $\mathrm{m} / z$.

previous studies is the relative intensities of $m / z, 43\left(\mathrm{C}_{2} \mathrm{H}_{3} \mathrm{O}^{+}\right.$ and $\left.\mathrm{C}_{3} \mathrm{H}_{7}^{+}\right)$and $m / z 44\left(\mathrm{CO}_{2}^{+}\right)$. At $f$ Peak $=0$, the $43 / 44$ ratio is 0.24 for OOA- 1 and 0.38 for OOA-2, while at $f$ Peak $=0.5$ this ratio is 0.25 for OOA- 1 and 0.66 for OOA-2.) Further, the $f$ Peak $=0.5$ spectra are similar to those obtained for 4 factor solutions obtained from PMF analysis of the individual Harrow and Bear Creek datasets. Therefore, the data reported below are taken exclusively from the $f$ Peak $=0.5$ solution. The time series for the $f$ Peak $=0$ and $f$ Peak $=0.5$ datasets are similar; comparisons of the time series for each factor at $f$ Peak $=0$ and $f$ Peak $=0.5$ yield $R=0.955$ for OOA-2 and $R>0.992$ for the other factors. Factor mass spectra and time series (at $f$ Peak $=0.5$ ) are shown in Figs. 1 and 2 , respectively. A comparison of the $f$ Peak $=0.5$ combined solution with the solution at $f$ Peak $=0$ and the individual Harrow and Bear Creek datasets is contained in the Supplement (Figs. S2 to S9). The factor mass spectra in Fig. 1 are similar to spectra obtained from PMF analysis of other AMS datasets (e.g. Slowik et al., 2010; Ulbrich et al., 2009; Lanz et al., 2007). In addition to the factor time series, Fig. 2 also contains time series of selected tracer species, which are discussed below.

HOA is likely dominated by primary anthropogenic emissions and exhibits temporal correlation with anthropogenic emission tracers such as toluene $(R=0.55$ at Harrow; not measured at Bear Creek) and a slight correlation with $\mathrm{NO}_{\mathrm{x}}$ ( $R=0.15$ at Harrow, 0.21 at Bear Creek) (see Fig. 2). Despite the slight correlation with $\mathrm{NO}_{\mathrm{x}}$, inspection of Fig. 2 indicates that elevated HOA typically corresponds to elevated $\mathrm{NO}_{\mathrm{x}}$; the low R-value is caused by periods of elevated $\mathrm{NO}_{\mathrm{x}}$ that do not contain significant concentrations of HOA. Such high $\mathrm{NO}_{\mathrm{x}}$ /low HOA periods would be expected from sources such as gasoline vehicles, which were known to periodically 


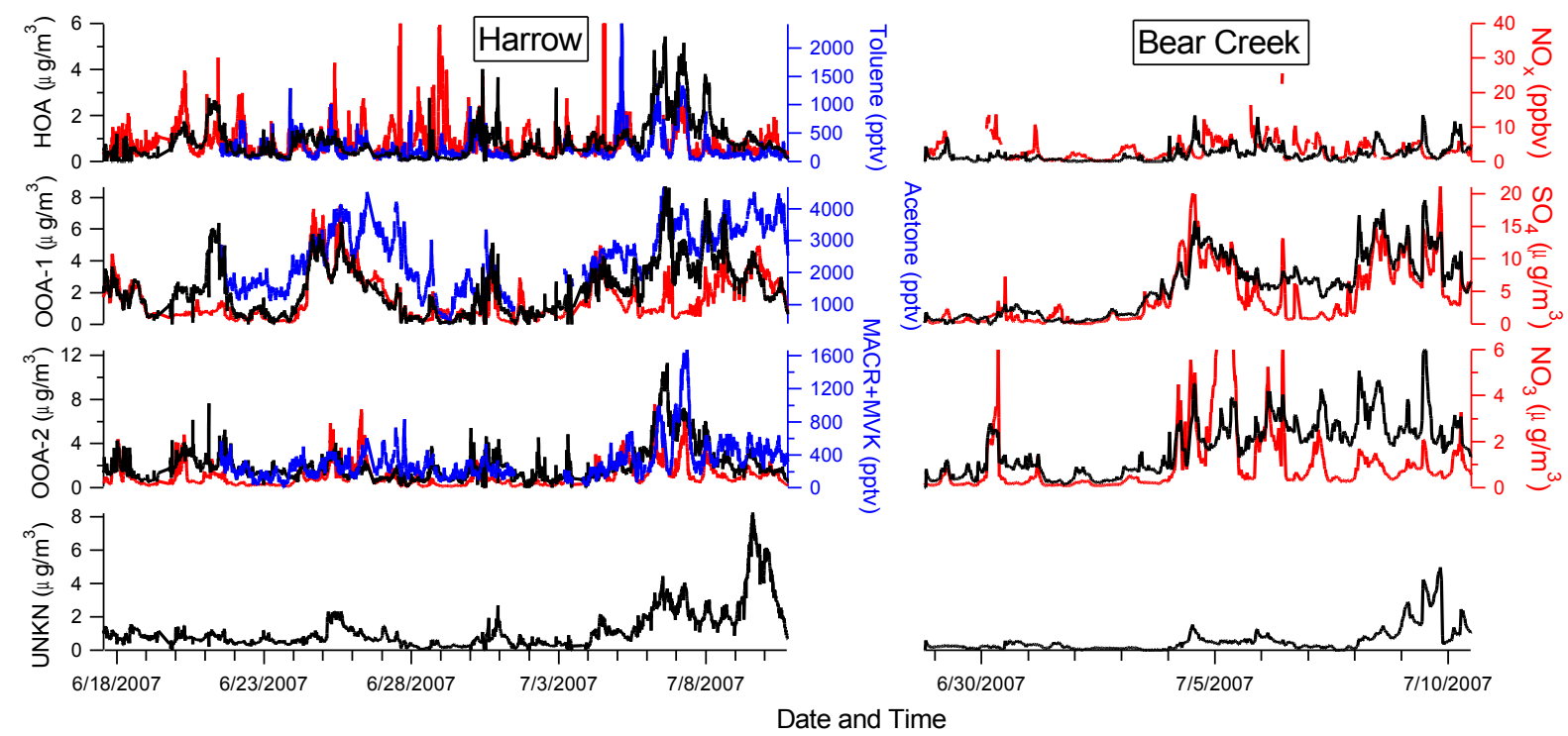

Fig. 2. Factor time series for the 4-factor PMF solution to the combined Harrow/Bear Creek dataset obtained at $f$ Peak $=0.5$. The figure also includes selected tracer species (blue and red traces).

influence the site. The factor mass spectrum is similar to previously reported HOA spectra (e.g. Slowik et al., 2010; Ulbrich et al., 2009; Lanz et al., 2007), as well as unburnt fuel and lubricating oil (Zhang et al., 2005). The spectrum is dominated by mass fragments characteristic of alkanes $(\mathrm{m} / \mathrm{z} 29,43,57,71, \ldots)$ and a second $\mathrm{m} / \mathrm{z}$ series $(\mathrm{m} / \mathrm{z} 27,41$, $55,69, \ldots)$ possibly resulting from $\mathrm{H}_{2}$-neutral losses from alkyl fragments (Zhang et al., 2005). This second series may result from alkenes; low molecular weight species are known to be present in diesel exhaust (McLaren et al., 1996a, b), likely due to $\mathrm{H}_{2}$-neutral losses and demethylation processes in the combustion chamber (Siegl, 1992), and it is likely that higher molecular weight species are present as well.

The OOA-1 and OOA-2 factor mass spectra are also similar to those obtained in other locations (e.g. Slowik et al., 2010; Ulbrich et al., 2009; Lanz et al., 2007). An important difference between the two factors is the fractional contribution of the $\mathrm{CO}_{2}^{+}$ion $(\mathrm{m} / \mathrm{z}, 44)$, which is approximately proportional to the elemental O:C ratio (Aiken et al., 2008). For OOA- $1, m / z 44$ constitutes 0.23 of the spectrum (O:C $\sim 0.96$ ), versus 0.11 (O:C $\sim 0.50$ ) for OOA-2. In Fig. 2 , the OOA-1 and OOA-2 time series are correlated with AMS measurements of particulate inorganic species and PTR-MS VOC measurements. OOA-1 correlates with particulate $\mathrm{SO}_{4}^{2-}$ ( $R=0.60$ at Harrow; 0.86 at Bear Creek) and acetone (0.72 at Harrow; not measured at Bear Creek), both of which are long-lived (i.e. more than a few days) and strongly influenced by regional transport. The correlations between OOA2 and (1) particulate $\mathrm{NO}_{3}^{-}(R=0.53$ at Harrow; 0.44 at Bear Creek) and (2) short-lived (i.e. $<1$ day) gas-phase oxidation products methacrolein + methyl vinyl ketone $(R=0.59$ at Harrow; not measured at Bear Creek) respectively suggest that OOA-2 is more volatile and fresher than OOA-1. These hypothesized volatility and age differences are consistent with the conclusions of previous studies (e.g. Slowik et al., 2010).

UNKN is a minor component of the organic aerosol except during the final 3 days of the study, when winds shift to the south/southwest. The factor is unique in having significant signal at $m / z 82$. The $m / z, 82$ time series is wellrepresented by the solution, with the correlation of raw and reconstructed data yielding $R=0.96$. HR-ToF-AMS measurements at Bear Creek indicate that the signal at this ion is dominated by $\mathrm{C}_{5} \mathrm{H}_{6} \mathrm{O}^{+}$and a lesser contribution from $\mathrm{C}_{6} \mathrm{H}_{10}^{+}$with $\mathrm{H}_{2} \mathrm{SO}_{3}^{+}$constituting only a few percent of the total. Recent studies conducted in the tropical forest indicated the presence of methylfuran in the condensed phase (Robinson et al., 2011), postulated to result from isoprene photooxidation. The UNKN factor identified in this study was likewise observed during a period of high isoprene and low aromatics, suggesting a biogenic influence (Sjostedt et al., 2010). We therefore tentatively attribute the observed $\mathrm{C}_{5} \mathrm{H}_{6} \mathrm{O}^{+}$to methylfuran, although other structures are possible. A second unusual peak occurs at $m / z 31$, and HR-ToFAMS measurements suggest this is due to $\mathrm{CH}_{3} \mathrm{O}^{+}$, which likely consists of $\mathrm{CH}_{3}-\mathrm{O}^{+}$(probably from a methyl ester or ether) and/or $\mathrm{H}_{2} \mathrm{C}=\mathrm{OH}^{+}$(probably from an alcohol). Strong signal at $m / z, 31$ and 82 is unusual for ambient AMS spectra, which suggests that the factor can be attributed to very fresh aerosol, because AMS spectra tend to become similar (i.e. OOA-1-like) with age across a variety of environments, independent of the initial source(s) (e.g. $\mathrm{Ng}$ et al., 2010; Jimenez et al., 2009; Capes et al., 2008). The $\mathrm{CO}_{2}^{+}$ion $(\mathrm{m} / \mathrm{z}, 44)$ constitutes only 0.01 of the spectrum, suggesting a 
Table 1. Ratio of species concentration $\left(\mu \mathrm{g} \mathrm{m}^{-3}\right)$ to $\mathrm{CO}(\mathrm{ppmv})$, with a CO background of 0.08 ppmv subtracted. SOA is estimated as OOA-1 + OOA-2 + UNKN.

\begin{tabular}{|c|c|c|c|c|c|c|c|}
\hline & \multicolumn{2}{|c|}{ Harrow $\rightarrow$ BC } & \multicolumn{2}{|c|}{$\mathrm{BC} \rightarrow$ Harrow } & \multicolumn{3}{|c|}{ Detroit/Windsor Plume } \\
\hline & Harrow & $\mathrm{BC}$ & $\mathrm{BC}$ & Harrow & $\mathrm{BC}$ & $\begin{array}{r}\text { Harrow } \\
(\min )\end{array}$ & $\begin{array}{c}\text { Harrow } \\
(\max )\end{array}$ \\
\hline OOA-1 & 19.3 & 38.1 & 4.4 & 8.8 & 13.4 & 6.6 & 93.9 \\
\hline OOA-2 & 10.9 & 37.5 & 34.8 & 23.2 & 27.8 & 8.7 & 120.1 \\
\hline HOA & 8.0 & 4.8 & 2.0 & 13.5 & 1.7 & 4.8 & 41.3 \\
\hline UNKN & 8.1 & 5.0 & 2.0 & 5.8 & 4.5 & 4.7 & 47.5 \\
\hline Org & 47.6 & 84.7 & 44.6 & 48.9 & 45.3 & 25.8 & 309.7 \\
\hline SOA & 38.3 & 80.5 & 41.2 & 37.8 & 45.7 & 20 & 259.7 \\
\hline $\mathrm{SO} 4$ & 41.7 & 87.4 & 12.7 & 17.6 & 11.8 & 2.4 & 100 \\
\hline
\end{tabular}

low O:C ratio consistent with fresh emissions. During the highest concentrations of the UNKN factor ( 9 July), AMS measurements indicate a sulfate plume (see Fig. 1). This agrees with AURAMS air quality model predictions of a sulfate plume from the Ohio Valley region (Stroud et al., 2010). Taken together with the evidence for biogenic activity discussed above, this observation suggests the UNKN factor may be due to the reactive uptake of isoprene onto preexisting sulfate aerosol and/or condensation of early-generation isoprene reaction products. Although this factor is classified as a "secondary factor" for the analysis below, this classification does not significantly affect the results because UNKN consitutes a minor fraction of the total aerosol during the selected case study periods (see Table 1).

\subsection{Description of case study periods}

Figure 3 shows the AMS time series for inorganic species and total organics (Fig. 3a), as well as the PMF factors discussed in the previous section (Fig. 3b). The figure contains three shaded regions corresponding to case study time periods discussed below. Green shading denotes a period of north-to-south flow (referred to here as Bear Creek-toHarrow) and red shading indicates south-to-north flow (denoted Harrow-to-Bear Creek). During the blue shaded period, the sampling region was influenced by outflow from the Detroit/Windsor/Windsor urban area. While we use the Bear Creek-to-Harrow and Harrow-to-Bear Creek labels for clarity, the periods should be viewed more generally as northerly and southerly flow, as opposed to direct flow proceeding unambiguously from one site to the other. A brief discussion of the particle sources and composition during each period follows.

For the period of Bear Creek-to-Harrow transport (29 June to 1 July, green shading), air arrives at the sample site from sparsely populated regions to the north. Back trajectories to both sites during this period are shown in Fig. 4. OA concentrations as a function of wind direction and speed are
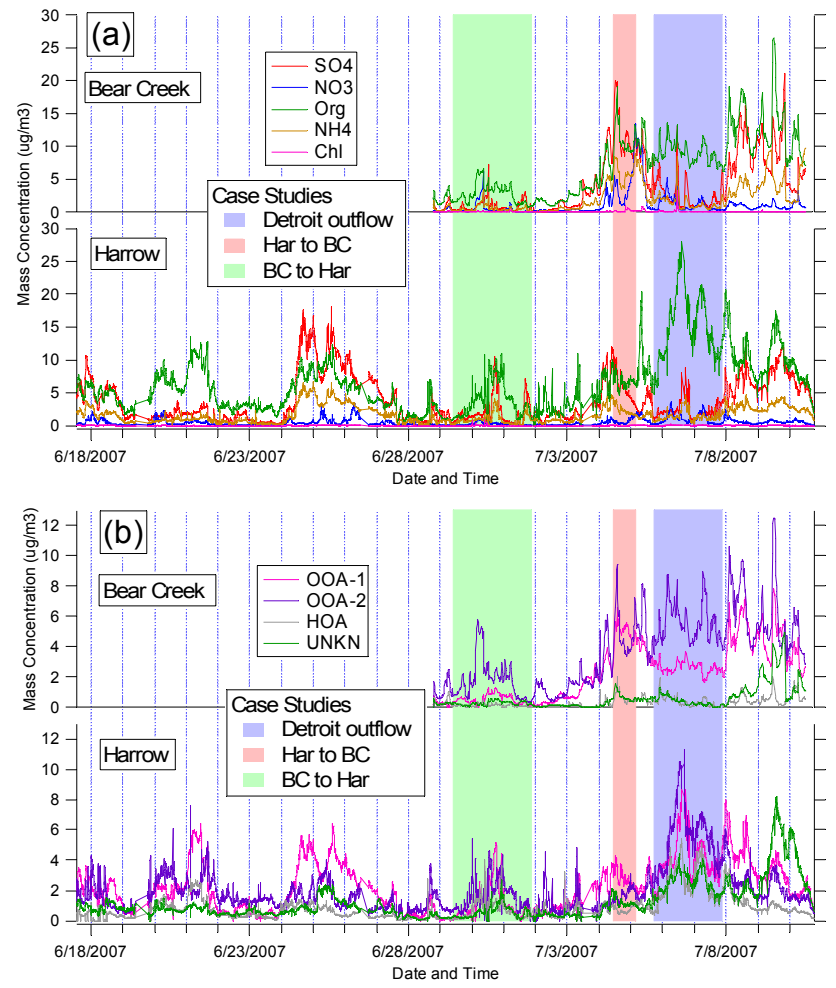

Fig. 3. AMS time series of inorganic species and total organics (a) and organic PMF factors (b). Shaded regions denote case study periods discussed in the text.

presented in the Supplement (Fig. S1). The HYSPLIT trajectories (Fig. 4a) show northerly flow, while local wind directions (Fig. S1a and b) indicate flow from the north/northeast. Taken together and as shown by the high-resolution trajectories (Fig. 4b), this suggests that the airmass follows a path passing east of the Detroit/Windsor region and thus brings relatively aged air that is relatively unaffected by fresh anthropogenic emissions. Figure 3 shows that the particle 


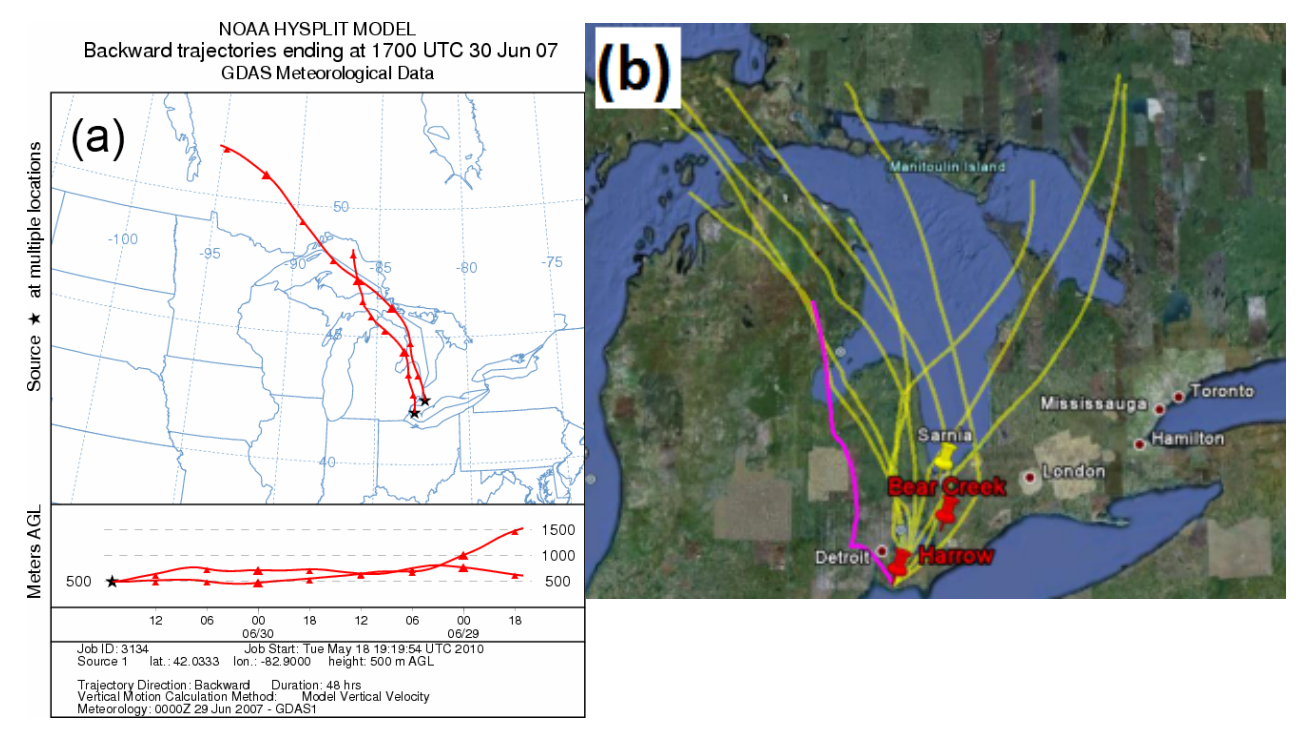

Fig. 4. Airmass sources during the Bear Creek-to-Harrow period (see Fig. 3, green period). Figure 4a shows HYSPLIT back trajectories to the Harrow and Bear Creek sites. Figure 4b shows high-resolution back trajectories to the Harrow site; the pink trajectory corresponds to the time period excluded from analysis (see text).

composition is dominated by organics. Sulfate levels are below $2 \mu \mathrm{g} \mathrm{m}^{-3}$, except during afternoon events on 30 June and 1 July at both sites. The Harrow sulfate event on 1 July and both Bear Creek sulfate events are likely due to the petrochemical industry emissions from Sarnia, ON and/or the Lambton coal-fired power plant $(\sim 10 \mathrm{~km}$ south of Sarnia). These events do not appear to affect the OA composition. However, the 30 June sulfate event at Harrow corresponds with a change in wind direction to the southwest (see Fig. 3c). As is evident from Figs. 2 and 3, sulfate during this event correlates with OOA-1, similar to the observed power plant emissions during the Harrow-to-Bear Creek period, discussed below. Additionally, $\mathrm{SO}_{2}$ levels are much higher during the 30 June event at both sites than at other times during the period (including 1 July). These observations suggest that the Harrow measurements during the 30 June sulfate event do not represent Bear Creek-to-Harrow transport. The high $\mathrm{SO}_{2}$ suggests fresh emissions; likely sources include the Detroit/Windsor area and/or a major coal-fired power plant in Monroe, MI, on the western shore of Lake Erie. This analysis is supported by high-resolution back trajectories (Fig. 4b, pink trajectory). Therefore measurements on 30 June from 14:50 to $16: 15$ are excluded from further analysis. As discussed in Sect. 3.4, trends in the concentration of primary and secondary organic aerosol factors at the two sites suggest that emissions between Harrow and Bear Creek do not drive inter-site changes in the organic aerosol composition.

During the Harrow-to-Bear Creek period (4 July to 5 July, red shading in Fig. 3), air is transported to the sample region from the south/southwest. This is shown by back trajectories (Fig. 5) and wind rose plots colored by OA concentration (Fig. S2). The trajectories suggest that air arriving at Bear
Creek passed very close to the Detroit/Windsor area; possible influences of this plume on the Bear Creek measurements are discussed in Sect. 3.4. $\mathrm{SO}_{2}$ emissions from power plants in the Ohio Valley are expected to strongly influence the particle composition. This is reflected in the high concentrations of particulate sulfate (see Fig. 3). Organics are dominated by SOA species, i.e. OOA-1 and OOA-2, which taken together constitute $68 \%$ of OA at Harrow and $89 \%$ at Bear Creek during this period. Transport of this type also occurs from 24 June to 27 June, resulting in similar aerosol composition. However, Bear Creek measurements are not available for the 24-27 June period.

From 5 June to 7 June (blue-shaded region in Fig. 3), the sampling region was influenced by the Detroit/Windsor outflow. Similar to the other case studies, Fig. 6 shows back trajectories and Fig. S3 shows wind rose plots for this period. Similar to the Bear Creek-to-Harrow period (Fig. 4a), back trajectories for the Detroit/Windsor period (Fig. 6a) indicate that the airmass originates from sparsely populated areas to the north/northwest of the sampling region. In contrast, measurements of local wind speed and direction at the Harrow site (Fig. S3a) show prevalent westerly winds. These observations, together with high-resolution back trajectories (Fig. 6b) suggest that the airmass samples emissions from the Detroit/Windsor area, continues southwards to Lake Erie, and then back N/NE in the lake breeze to Harrow. The age of the Detroit/Windsor plume varies from $\sim 0.5$ to $>1$ day (Levy et al., 2010); this variation in age is reflected in the $\mathrm{NO}_{\mathrm{x}} / \mathrm{NO}_{\mathrm{y}}$ ratio, as discussed in the next section. In contrast, back trajectories to Bear Creek pass east of Detroit/Windsor, and local wind direction is variable. This suggests that during this period, Bear Creek is not strongly influenced by 


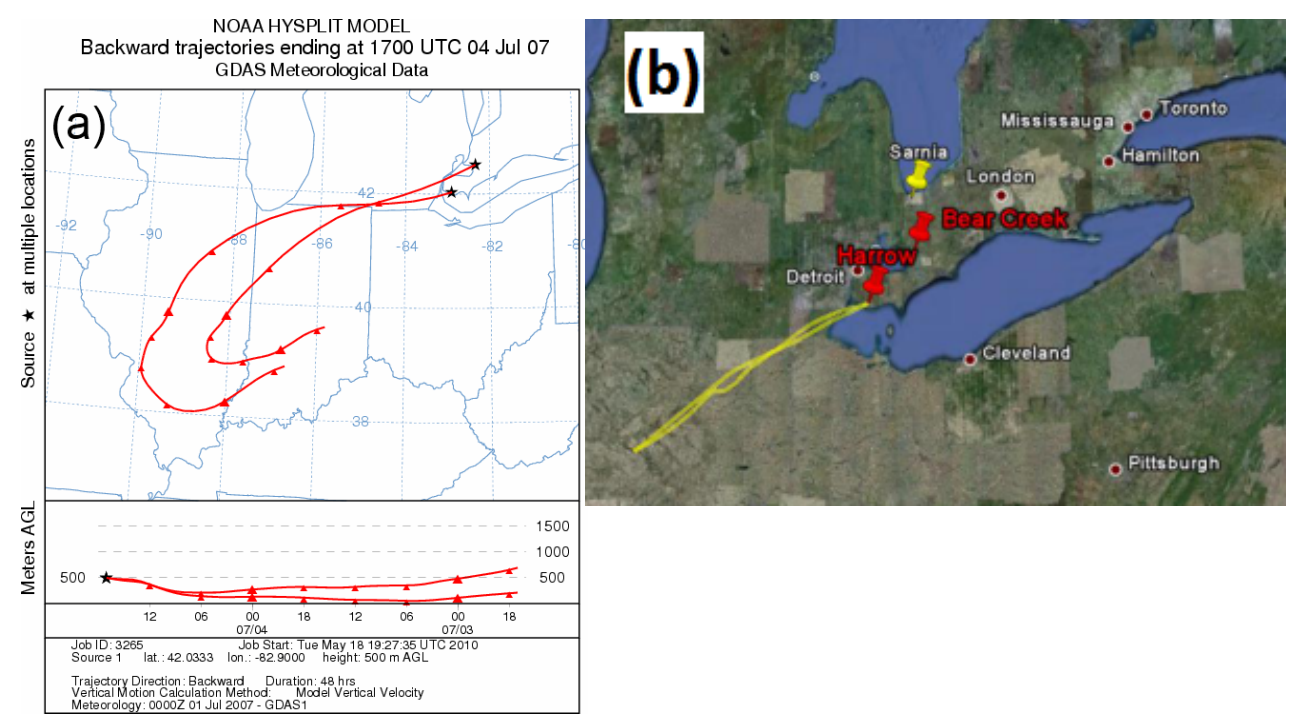

Fig. 5. Airmass sources during the Harrow-to-Bear Creek period (see Fig. 3, red period). (a) shows HYSPLIT back trajectories to the Harrow and Bear Creek sites. (b) shows high-resolution back trajectories to the Harrow site.

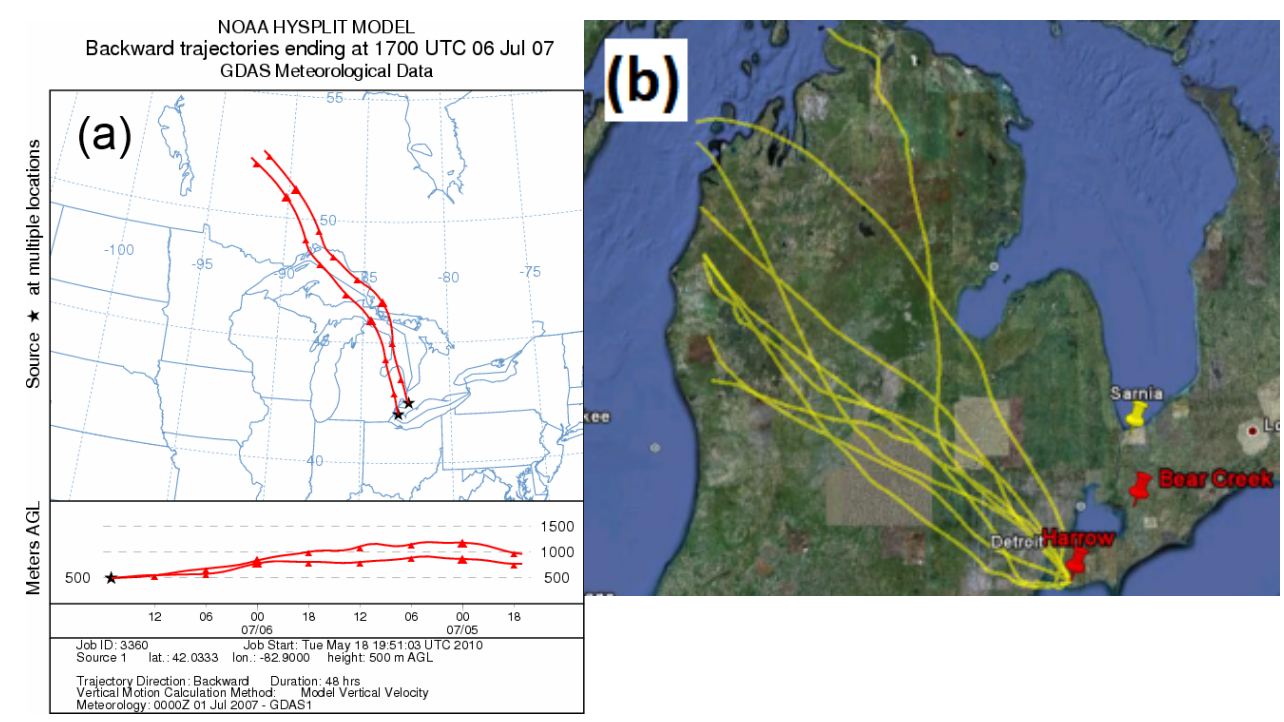

Fig. 6. Airmass sources during the Detroit/Windsor outflow period (see Fig. 3, blue period). (a) shows HYSPLIT back trajectories to the Harrow and Bear Creek sites. (b) shows high-resolution back trajectories to the Harrow site.

Detroit/Windsor air. Such an interpretation is supported by the chemical data, as discussed below.

\subsection{Photochemical processing as characterized by $\mathrm{NO}_{\mathrm{x}} / \mathrm{NO}_{\mathrm{y}}$ ratio}

Figures 7 to 9 consider photochemical aging by investigating the CO-normalized organic components as a function of the $\mathrm{NO}_{\mathrm{x}} / \mathrm{NO}_{\mathrm{y}}$ ratio, changes to which are taken as an indication of photochemical processing. $\mathrm{NO}_{\mathrm{x}}\left(\mathrm{NO}+\mathrm{NO}_{2}\right)$ is mostly emitted as $\mathrm{NO}$ a steady-state mixture with $\mathrm{NO}_{2}$ is rapidly formed by reaction with $\mathrm{O}_{3}$. Further oxidation reactions yield species such as $\mathrm{HNO}_{3}$, PAN, and organic nitrates. The total of $\mathrm{NO}_{\mathrm{x}}$ and its oxidation products are denoted as $\mathrm{NO}_{\mathrm{y}}$. In Figs. 7 to 9 , we use the quantity $-\log \left(\mathrm{NO}_{\mathrm{x}} / \mathrm{NO}_{\mathrm{y}}\right)$ as a surrogate for photochemical age. For fresh emissions, $-\log \left(\mathrm{NO}_{\mathrm{x}} / \mathrm{NO}_{\mathrm{y}}\right)=0$, and $-\log \left(\mathrm{NO}_{\mathrm{x}} / \mathrm{NO}_{\mathrm{y}}\right)=1$ when $90 \%$ of $\mathrm{NO}_{\mathrm{x}}$ is converted to $\mathrm{NO}_{\mathrm{y}}$. This expression has been previously used as an estimate of photochemical age the Mexico City plume (Kleinman et al., 2008).

The $\mathrm{NO}_{\mathrm{x}} / \mathrm{NO}_{\mathrm{y}}$ ratio provides a crude estimate of the photochemical age. We assume that the major $\mathrm{NO}_{\mathrm{x}}$ loss process 

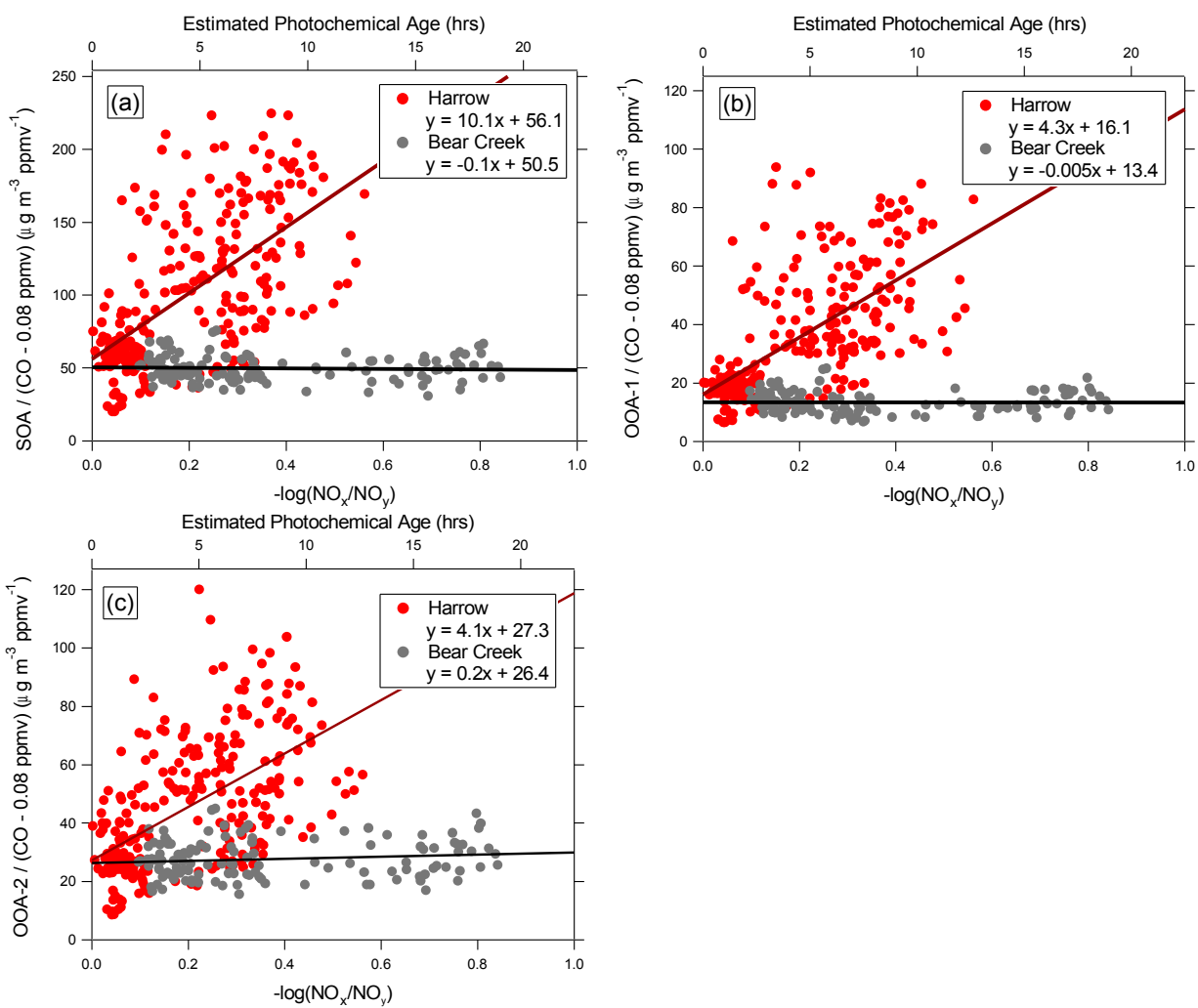

Fig. 7. Photochemical aging at Harrow and Bear Creek during Detroit/Windsor outflow (see Fig. 3 blue period, and Fig. 6). CO-normalized values for (a) SOA (estimated as OOA-1 + OOA-2 + UNKN), (b) OOA-1, and (c) OOA-2 are plotted as a funciton of $-\log \left(\mathrm{NO}_{\mathrm{x}} / \mathrm{NO}_{\mathrm{y}}\right)$. For curve fitting results, slopes are reported in $\mu \mathrm{g} \mathrm{m}^{-3} \mathrm{ppmv}^{-1} \mathrm{~h}^{-1}$ and intercepts are in $\mu \mathrm{g} \mathrm{m}^{-3} \mathrm{ppmv}^{-1}$.
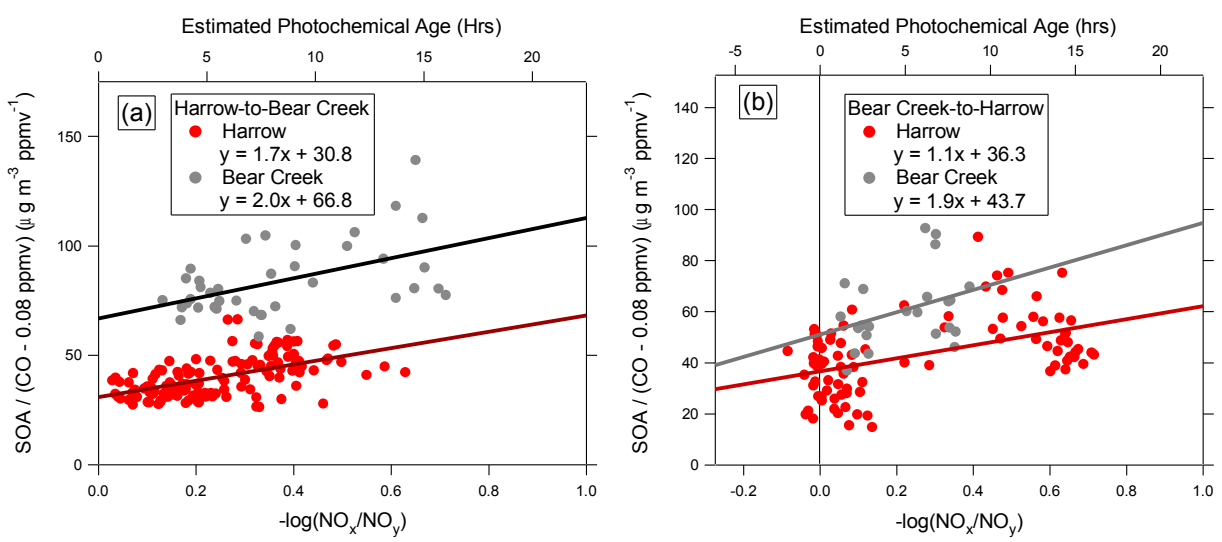

Fig. 8. Photochemical aging during periods of transport between Harrow and Bear Creek. As in Fig. 6, SOA is estimated as OOA-1 + OOA$2+$ UNKN. Similar slopes represent similar responses to local processing, reflected in the $\mathrm{NO}_{\mathrm{x}} / \mathrm{NO}_{\mathrm{y}}$ ratio. Differences in the $\mathrm{y}$-intercepts represent airmass processing during inter-site transport, as discussed in the text. Figure 8a shows the Harrow-to-Bear Creek period (see Fig. 3 red period, and Fig. 5); Fig. 8 b shows Bear Creek-to-Harrow (see Fig. 3 green period, and Fig. 4). For curve fitting results, slopes are reported in $\mu \mathrm{g} \mathrm{m}^{-3} \mathrm{ppmv}^{-1} \mathrm{~h}^{-1}$ and intercepts are in $\mu \mathrm{g} \mathrm{m}^{-3} \mathrm{ppmv}^{-1}$.

is the reaction $\mathrm{OH}+\mathrm{NO}_{2} \rightarrow \mathrm{HNO}_{3}$. The photochemical age $\Delta t$ can therefore be represented as:

$\frac{\left[\mathrm{NO}_{\mathrm{x}}\right]_{t}}{\left[\mathrm{NO}_{\mathrm{x}}\right]_{0}}=e^{-k[\mathrm{OH}] \Delta t}$
We assume all $\mathrm{NO}_{\mathrm{y}}$ originates as $\mathrm{NO}_{\mathrm{x}}$ and that there are no significant local sources of $\mathrm{NO}_{\mathrm{x}}$. Therefore $\left(\mathrm{NO}_{\mathrm{x}}\right)_{0}=\left(\mathrm{NO}_{\mathrm{y}}\right)$. The rate constant $k$ is estimated to be $7.9 \times 10^{-12} \mathrm{~cm}^{3} \mathrm{~s}^{-1}$ at $1 \mathrm{~atm}$ and $300 \mathrm{~K}$ using the parameterization of Brown 


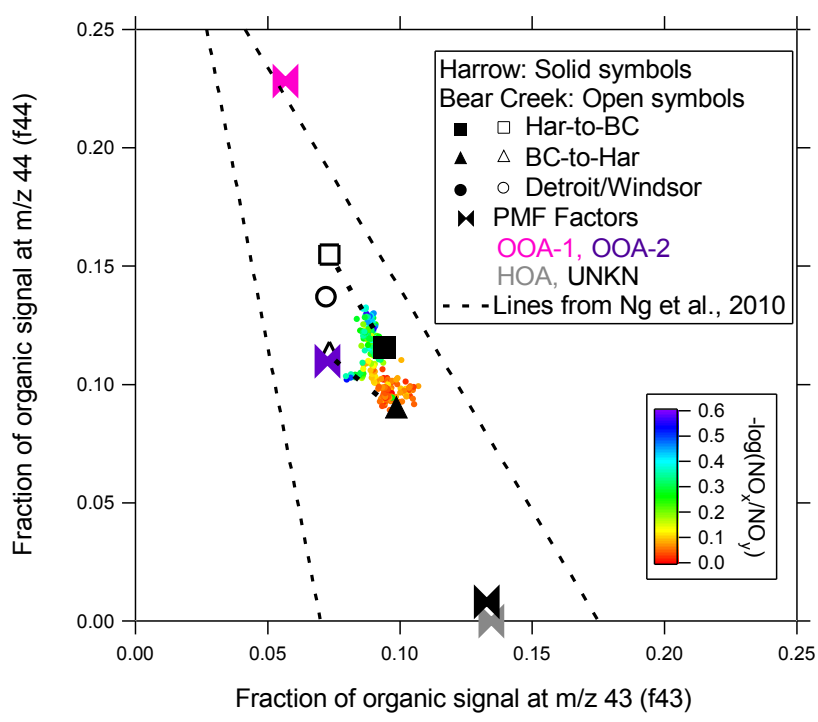

Fig. 9. Fraction of organic signal at $m / z 43$ and $44(f 43, f 44)$ at each site during the three case study periods. All measurements are shown for the highly photochemical age-dependent measurements of the Detroit/Windsor plume at Harrow (see Fig. 7); otherwise, average values are shown. Dashed lines colored for the inter-site transport periods (Harrow-to-Bear Creek and Bear Creekto-Harrow) connect measurements at the two sites to guide the eye. Values are also shown for the 4 PMF factors. Dashed black lines denote the approximate range of $f 44$ and $f 43$ from ambient OOA-1 and OOA-2 factors (Ng et al., 2010).

et al. (1999). The mean daytime $(\mathrm{OH})$ is estimated at $3.6 \times 10^{6}$ molec $\mathrm{cm}^{-3}$ from the ratios of toluene and $\mathrm{C}_{8}$ aromatics (Sjostedt et al., 2010). The estimated photochemical age therefore corresponds to effective daylight hours.

This estimate does not account for nocturnal $\mathrm{NO}_{\mathrm{x}}$ loss via $\mathrm{N}_{2} \mathrm{O}_{5}$ hydrolysis, which is known to be a major $\mathrm{NO}_{\mathrm{x}}$ sink in some regions. Diurnal profiles for $-\log \left(\mathrm{NO}_{\mathrm{x}} / \mathrm{NO}_{\mathrm{y}}\right)$ (see Fig. S10) show that the ratio is stable overnight, but increases during the day at a rate approximately consistent with the estimated photochemical age. This suggests that photochemical reactions are the primary influence on the $\mathrm{NO}_{\mathrm{x}} / \mathrm{NO}_{\mathrm{y}}$ ratio, although other influences cannot be ruled out. The photochemical age estimate also does not account for other $\mathrm{NO}_{\mathrm{x}}$ loss processes or reservoirs, e.g. $\mathrm{NO}_{\mathrm{x}}$ production by photolysis of $\mathrm{HNO}_{3}$, nocturnal conversion to $\mathrm{HNO}_{3}$ by reaction of $\mathrm{NO}_{2}$ with $\mathrm{O}_{3}$ and $\mathrm{H}_{2} \mathrm{O}$, formation of PAN, etc. Using the above method, we estimate that $\mathrm{NO}_{\mathrm{x}} / \mathrm{NO}_{\mathrm{y}}$ ratios of $0.9,0.5$, and 0.1 correspond to $\sim 1 \mathrm{~h}, \sim 7 \mathrm{~h}$, and $\sim 22 \mathrm{~h}$, respectively.

In considering these figures, a distinction should be drawn between using the $\mathrm{NO}_{\mathrm{x}} / \mathrm{NO}_{\mathrm{y}}$ ratio as an estimate of absolute photochemical age vs. using changes in the ratio as an indication of photochemical processing. The former assumes the ratio to be governed by compounds emitted at the source and their subsequent reactions. However, the presence of significant $\mathrm{NO}_{\mathrm{x}}$ sources between the initial source and the measurement site may revert the ratio to values indicating unprocessed aerosol, if these sources are stronger than the diluted initial plume. Such is likely the case for the regional aerosol sampled at Bear Creek in Fig. 7 and at both sites in Fig. 8: fresh $\mathrm{NO}_{\mathrm{x}}$ emissions were injected into an existing regional aerosol. In the present study, examples of likely sources of such emissions include the highway running perpendicular to the Harrow/Bear Creek transect, as well as secondary highways and rural roads in this region. Therefore, equal $\mathrm{NO}_{\mathrm{x}} / \mathrm{NO}_{\mathrm{y}}$ ratios do not necessarily indicate identical photochemical ages when one compares different airmasses or the same airmass sampled at different sites. However, once the $\mathrm{NO}_{\mathrm{x}} / \mathrm{NO}_{\mathrm{y}}$ ratio has been reverted to "fresh" values, the ratio again decreases with age. Therefore, we assume that for a single airmass sampled at a single site, the dependence of aerosol composition on the $\mathrm{NO}_{\mathrm{x}} / \mathrm{NO}_{\mathrm{y}}$ ratio (i.e. the slopes in Figs. 7 and 8) can be used to compare photochemical processing rates on comparable timescales. For a given time period, intercepts will be the same at the two sites only if (1) both airmasses originate from the same location and (2) all photochemical aging is reflected in the $\mathrm{NO}_{\mathrm{x}} / \mathrm{NO}_{\mathrm{y}} \mathrm{ra}-$ tio.

The Detroit/Windsor plume is characterized by rapid SOA formation from oxidative processing. Figures 7 and 8 show CO-normalized concentrations of SOA (estimated as OOA$1+$ OOA-2 + UNKN), and the OOA-1 and OOA-2 components (Fig. 7 only) as a function of photochemical age. Photochemical age is represented by the $\mathrm{NO}_{\mathrm{x}} / \mathrm{NO}_{\mathrm{y}}$ ratio, plotted as $-\log \left(\mathrm{NO}_{\mathrm{x}} / \mathrm{NO}_{\mathrm{y}}\right)$. Note that the similar range of $\mathrm{NO}_{\mathrm{x}} / \mathrm{NO}_{\mathrm{y}}$ ratios during the two periods reflect the influence of diurnal cycles, i.e. sunlight, on the $\mathrm{NO}_{\mathrm{x}}$ chemistry and photochemical age. Particulate organic concentrations are normalized to $\mathrm{CO}$ to account for dilution, with a $\mathrm{CO}$ background of 0.08 ppmv subtracted prior to normalization, consistent with summer measurements in the Northern Hemisphere (Li et al., 2004; Parrish et al., 2004). To reduce the influence of outlying values caused by low CO levels, only data where $\mathrm{CO}>0.15 \mathrm{ppmv}$ are considered. $\mathrm{CO}$ is co-emitted with combustion-related anthropogenic SOA precursors and has a relatively long atmospheric lifetime, thus its concentration at the measurement sites is expected to be mostly governed by emissions source strength and dilution. Although photochemically-produced $\mathrm{CO}$ can constitute a large fraction of total $\mathrm{CO}$ in airmasses dominated by biogenic emissions (Slowik et al., 2010; Hudman et al., 2008; Miller et al., 2008), this is expected to constitute a minor source in polluted air, such as that observed during the Detroit/Windsor and Harrow-to-Bear Creek periods. However, a contribution from photochemically-produced CO during the relatively clean Bear Creek-to-Harrow period cannot be ruled out. Generally, increases in the organic to $\mathrm{CO}$ ratio are expected to represent atmospheric processing as polluted air moves away from the source (e.g. Kleinman et al., 2009, de Gouw et al., 2008, 2005; DeCarlo et al., 2008). 
We first consider the Detroit/Windsor outflow period (Fig. 7). In particular, the Harrow data show a strong positive correlation of (CO-normalized) SOA, OOA-1, and OOA-2 mass with photochemical age. In contrast, the mass of these components at the Bear Creek site is nearly independent of the $\mathrm{NO}_{\mathrm{x}}$-based estimate of photochemical age. This suggests that Bear Creek is not strongly influenced by Detroit/Windsor outflow during this period and that the particle composition is characteristic of a more regional aerosol. Unlike Harrow, values for $-\log \left(\mathrm{NO}_{\mathrm{x}} / \mathrm{NO}_{\mathrm{y}}\right)$ at Bear Creek do not go below $\sim 0.1$, supporting the inference of more aged/regional aerosol at Bear Creek discussed above. The slope of the CO-normalized SOA vs. $-\log \left(\mathrm{NO}_{\mathrm{x}} / \mathrm{NO}_{\mathrm{y}}\right)$ plot (Fig. 7a) at Harrow is considerably larger than that observed in airborne measurements of Mexico City outflow taken up to 1 day from the source (slope of CO-normalized SOA vs. $-\log \left(\mathrm{NO}_{\mathrm{x}} / \mathrm{NO}_{\mathrm{y}}\right.$ ) at Harrow $=189.2 \mu \mathrm{g} \mathrm{m}^{-3} \mathrm{ppmv}^{-1}$ vs. $71.4 \mu \mathrm{g} \mathrm{m}^{-3} \mathrm{ppmv}^{-1}$ at Mexico City) (Kleinman et al., 2008), but is in reasonably good agreement with ground site measurements at Mexico City characterizing aging over $\sim 6 \mathrm{~h}$ (Jimenez et al., 2009) (Harrow SOA increase $=10.1 \mu \mathrm{g} \mathrm{m}^{-3} \mathrm{ppmv}^{-1} \mathrm{~h}^{-1}$ vs. Mexico City SOA increase $=10.5 \mu \mathrm{g} \mathrm{m}^{-3} \mathrm{ppmv}^{-1} \mathrm{~h}^{-1}$ ). The reasons for these differences are not known, but may be related to (1) presence of biogenic SOA, (2) the age of the airmass sampled, and/or (3) assumptions inherent in the use of $\mathrm{NO}_{\mathrm{x}} / \mathrm{NO}_{\mathrm{y}}$ to estimate photochemical age.

Modeling studies indicate that SOA formed from oxidation of monoterpene precursors constitutes a significant fraction of the measured SOA, even within the Detroit/Windsor plume (Stroud et al., 2010). A biogenic SOA event observed north of Toronto exhibited a greatly enhanced organics/CO ratio $\left(234.4 \mu \mathrm{g} \mathrm{m}^{-3} \mathrm{ppmv}^{-3}\right)$, with the increase driven by the SOA component (Slowik et al., 2010).

The Detroit/Windsor plume was sampled approximately $6 \mathrm{~h}$ from the source vs. up to 1 day in Mexico City. Photochemical SOA production has been shown to slow as distance from the source increases (Jimenez et al., 2009) and precursors are consumed. While the trend at Harrow of increasing SOA/CO with photochemical age is clear in Fig. 7, such slowing was not observed. Further, the Mexico City results showed more rapid initial formation of OOA-2 over timescales of less than $3 \mathrm{~h}$; this is also not observed in the Detroit/Windsor plume. However, such trends in the Detroit plume could be masked by the significant scatter in the data (e.g. SOA/CO ranges from $\sim 40$ to $200 \mu \mathrm{g} \mathrm{m}^{-3} \mathrm{ppmv}^{-3}$ for $\left.-\log \left(\mathrm{NO}_{\mathrm{x}} / \mathrm{NO}_{\mathrm{y}}\right)=0.3\right)$. This scatter may be due to (1) changes in the strength and/or identity of sources contributing to the sampled plume, (2) biogenic SOA production, and/or (3) imperfections in the estimate of photochemical age.

The y-intercepts for each factor (i.e. SOA, OOA-1, OOA2) in Fig. 7 provide additional support for the interpretation of the Harrow and Bear Creek measurements during this period as characteristic of Detroit/Windsor outflow and regional aerosol, respectively. In this plot, the y-intercept may correspond to (1) primary emissions and/or (2) the regional background onto which the Detroit/Windsor plume is superimposed. That is, for a plume the y-intercept denotes conditions at the point of emissions (negligible aging), but the contribution of the plume cannot be distinguished from preexisting aerosol, i.e. the regional background. As discussed above, the Bear Creek data likely represent this regional background. Figure 7 shows nearly identical yintercepts at the two sites for both the total SOA (Fig. 7a) and the individual OOA-1 and OOA-2 factors (Fig. 7b and c, respectively). This suggests that the Harrow y-intercepts also represent the regional background (which would be expected to be similar at the two sites), rather than primary emissions of oxygenated species in the Detroit/Windsor plume.

Figure 8 shows the normalized concentrations of SOA, OOA-1, and OOA-2 as a function of photochemical age during the Bear Creek-to-Harrow and Harrow-to-Bear Creek periods. Similar to the regional aerosol observed at the Bear Creek site during the Detroit/Windsor plume, these plots show at most a slight increase in mass with photochemical age. However, the two sites have different y-intercepts during the Harrow-to-Bear Creek period. As discussed in the following section, this suggests processing during inter-site transport.

\subsection{Photochemical processing from inter-site transport}

Periods of flow between the Bear Creek and Harrow sites permit characterization of the changes in regional aerosol composition. This provides a contrast with analysis of the Detroit/Windsor urban plume (see Sect. 3.3). Table 1 compares the organic composition at the two sampling locations during the periods of inter-site transport described above. During Harrow-to-Bear Creek transport, $\Delta$ organics/ $\triangle \mathrm{CO}$ increases by a factor of 1.78 (increase of $37.1 \mu \mathrm{g} \mathrm{m}^{-3} \mathrm{ppmv}^{-1}$ ), suggesting SOA formation on the timescale of inter-site transport. Such a mass increase is not observed during Bear Creek-to-Harrow transport, as $\Delta$ organics/ $\Delta \mathrm{CO}$ only increases by a factor of 1.10 (net increase of $4.3 \mu \mathrm{g} \mathrm{m}^{-3} \mathrm{ppmv}^{-1}$ ). This is consistent with slower SOA formation in an airmass that is older and/or more dilute with respect to anthropogenic and biogenic emissions sources. Further, it suggests emissions from the highway running perpendicular to the Bear Creek/Harrow transect did not significantly affect the particulate organics.

SOA formation during Harrow-to-Bear Creek transport is supported by inspection of the CO-normalized concentrations of the individual PMF factors. Table 1 shows that the increase in organic mass can be attributed to the OOA factors. This increase (and lack of increase during the Bear Creekto-Harrow period) are also evident from comparisons of the y-intercepts in Fig. 8. That is, the higher y-intercept at Bear Creek during the Harrow-to-Bear Creek period (Fig. 8a) suggests inter-site processing not accounted for by the $\mathrm{NO}_{\mathrm{x}} / \mathrm{NO}_{\mathrm{y}}$ 
ratio. Interestingly, Table 1 shows increases in both OOA1 and OOA-2, suggesting that SOA formation is occurring in both the more oxygenated/less volatile and less oxygenated/more volatile SOA components. For the Harrow-toBear Creek period (anthropogenically source-rich), increases in the OOA components are of similar magnitude $(\triangle \mathrm{OOA}$ 1: $18.8 \mu \mathrm{g} \mathrm{m}^{-3} \mathrm{ppmv}^{-1}$, a factor of 1.97 increase; $\triangle \mathrm{OOA}-2$ : $26.6 \mu \mathrm{g} \mathrm{m}^{-3} \mathrm{ppmv}^{-1}$, a factor of 3.44). For the Bear Creekto-Harrow period (sparse anthropogenic sources), OOA-1

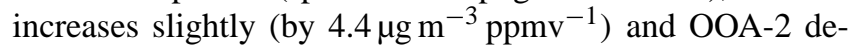
creases (by $11.6 \mu \mathrm{g} \mathrm{m}^{-3} \mathrm{ppmv}^{-1}$ ). These changes in composition may represent conversion of OOA-2 to OOA-1 through heterogeneous processing and/or gas-phase processing of OOA-2, which as described in Sect. 3.1 is expected to be somewhat volatile. The increases in normalized OOA-1 and OOA-2 shown in Table 1 for the Harrow-to-Bear Creek period are driven by increases in the component mass (OOA-1 and OOA-2 increase between sites by factors of 1.8 and 2.8, respectively) rather than by a decrease in $\mathrm{CO}$ (decreases by a factor of 0.95).

Table 1 also shows higher concentrations of primary species (i.e. HOA) at Harrow during both periods of inter-site transport. This is likely due to the influence of local emissions near the Harrow site, e.g. from local roads and activity at the Agriculture Canada site at which measurements were made. However, the concentrations of both factors are typically low $\left(<\sim 1 \mu \mathrm{g} \mathrm{m}^{-3}\right)$, except for a few brief periods of local emissions during which the concentrations of the OOA species are not significantly affected. Taken together, these two observations (i.e. higher primary factor concentrations at Harrow regardless of flow direction and consistently low concentrations at both sites) suggest that primary emissions between sites do not greatly affect the particle composition. For OOA-1 and OOA-2, the strikingly different behavior in the Harrow-to-Bear Creek vs. Bear Creek-to-Harrow periods indicates that emissions between sites do not drive the changes in SOA factor concentrations.

In interpreting the Harrow-to-Bear Creek data, an important question is the extent to which emissions from the Detroit/Windsor area affect particle composition, particularly at the Bear Creek site. Figure 5a shows that back trajectories arriving at Bear Creek during this period pass close to Detroit/Windsor; we therefore cannot altogether rule out some influence from this area. However, the following features of the Bear Creek chemical data suggest that the Detroit/Windsor plume does not drive the observed changes in particle composition between sites:

1. Concentrations of the primary organic factor HOA are low at Bear Creek. The mean value for CO-normalized HOA at Bear Creek $\left(4.8 \mu \mathrm{g} \mathrm{m}^{-3} \mathrm{ppmv}^{-3}\right)$ is equal to the minimum value observed at Harrow in the Detroit/Windsor plume (see Table 1). However, most observed values in the plume are considerably higher, reaching a maximum of $41.3 \mu \mathrm{g} \mathrm{m}^{-3} \mathrm{ppmv}^{-3}$. Further, the absolute concentrations of HOA, shown in Fig. 3, are lower by a factor of 2 to 10 at Bear Creek during the Harrow-to-Bear Creek period than in the Detroit/Windsor plume at Harrow.

2. Mean CO values (see Table 2) are slightly lower at Bear Creek during the Bear Creek-to-Harrow period than at Harrow in the Detroit/Windsor plume. However, CO concentrations measured in the plume at Harrow feature numerous excursions as the plume location changes, yielding a maximum of $0.86 \mathrm{ppmv}$ and a standard deviation of 0.12 ppmv. In contrast, Bear Creek CO measurements during the Harrow-to-Bear Creek period are quite stable (standard deviation $=0.02 \mathrm{ppmv}$ ) and yield a maximum value of only $0.26 \mathrm{ppmv}$.

3. The fractional composition of organics at Bear Creek during the Harrow-to-Bear Creek period is distinct from composition in the Detroit/Windsor plume. As shown in Table 1, measurements of the Detroit/Windsor plume at Harrow shows HOA to be roughly a factor of 2 to 3 lower than each of the OOA factors. Figure 3 shows this value to be approximately consistent throughout the period. However, at Bear Creek during the Harrow-toBear Creek period, HOA is approximately a factor of 8 lower than either OOA factor. Further, measurements at Harrow during the Harrow-to-Bear Creek period show HOA to be no more than a factor of $\sim 2$ lower than the OOA factors. Therefore the particle composition during the Harrow-to-Bear Creek period becomes less similar to that in the Detroit/Windsor plume as the particles move between sites, suggesting that the plume is not driving particle composition.

Figure 9 shows the organic composition during the three case study periods discussed above. Here organic composition is represented according to the framework presented by $\mathrm{Ng}$ et al. (2010) for assessment of atmospheric aging. That is, organic composition is characterized by the fraction of organic signal at $m / z 43\left(\mathrm{C}_{3} \mathrm{H}_{7}^{+}\right.$and $\mathrm{C}_{2} \mathrm{H}_{5} \mathrm{O}^{+}$ions $)$and $\mathrm{m} / \mathrm{z} 44\left(\mathrm{CO}_{2}^{+}\right.$ion, approximately proportional to the O:C elemental ratio, Aiken et al., 2008). These quantities are denoted as $f 43$ and $f 44$, respectively. Points on the graph denote average values for the designated period, excepting Detroit/Windsor outflow at Harrow, where individual 5-min averages are shown. These values vary with photochemical age (i.e. $-\log \left(\mathrm{NO}_{\mathrm{x}} / \mathrm{NO}_{\mathrm{y}}\right)$, not shown), with more aged data tending towards the top left. Also shown in the figure are $f 43$ and $f 44$ for the four PMF factors discussed in Sect. 3.1 and lines representing the range of values observed in other studies for OOA-like species ( $\mathrm{Ng}$ et al., 2010). As discussed by $\mathrm{Ng}$ et al. (2010), atmospheric processing generally causes OA composition to move upwards and to the left in this space because of the addition of oxygenated functional groups. Such a trend is observed in the present study for the Harrow-to-Bear Creek period and Detroit/Windsor 
Table 2. Concentrations of $\mathrm{CO}$ (ppmv) and $\mathrm{NO}_{\mathrm{x}}$ (ppbv) at Harrow and Bear Creek during the Harrow-to-Bear Creek, Bear Creek-toHarrow, and Detroit/Windsor plume case study periods. Mean, standard deviation, minimum, and maximum values are reported for each period. Data during the Harrow-to-Bear Creek period at the Harrow site exclude an event on 4 July $(12: 25$ to $13: 40)$ where $\mathrm{NO}_{\mathrm{x}}$ is elevated without perturbing either the particle composition or $\mathrm{CO}$ concentration. If this event is included, the table entry reads as follows: mean $\mathrm{NO}_{\mathrm{x}}=8.8 \pm 17.9 \mathrm{ppbv}$, minimum $\mathrm{NO}_{\mathrm{x}}=1.2 \mathrm{ppbv}$, and maximum $\mathrm{NO}_{\mathrm{x}}=102.3 \mathrm{ppbv}$.

\begin{tabular}{|c|c|c|c|c|c|c|}
\hline & \multicolumn{2}{|c|}{ Harrow $\rightarrow$ BC } & \multicolumn{2}{|c|}{$\mathrm{BC} \rightarrow$ Harrow } & \multicolumn{2}{|c|}{ Detroit/Windsor Plume } \\
\hline & Harrow & $\mathrm{BC}$ & $\mathrm{BC}$ & Harrow & Harrow & $\mathrm{BC}$ \\
\hline mean $\mathrm{CO}$ & $0.22 \pm 0.02$ & $0.21 \pm 0.02$ & $0.13 \pm 0.03$ & $0.12 \pm 0.04$ & $0.25 \pm 0.12$ & $0.28 \pm 0.04$ \\
\hline$(\min , \max )$ & $(0.19,0.28)$ & $(0.18,0.26)$ & $(0.10,0.21)$ & $(0.06,0.29)$ & $(0.12,0.83)$ & $(0.22,0.39)$ \\
\hline mean $\mathrm{NO}_{\mathrm{x}}$ & $4.1 \pm 2.4$ & $5.0 \pm 3.2$ & $2.9 \pm 3.5$ & $4.6 \pm 3.4$ & $6.7 \pm 4.8$ & $4.3 \pm 3.9$ \\
\hline$(\min , \max )$ & $(1.2,13.1)$ & $(0.8,12.3)$ & $(0.2,13.6)$ & $(0.7,18.6)$ & $(0.8,18.6)$ & $(0.4,25.5)$ \\
\hline
\end{tabular}

plume processing observed at Harrow. However, the opposite behavior is seen during the Bear Creek-to-Harrow period because of the combination of low SOA mass and contamination from local primary emissions. When primary emissions factors (i.e. HOA and UNKN) are removed from the Bear Creek-to-Harrow period, these data also move towards the upper left with increasing age. This is implied in Table 1 by higher OOA-1 and lower OOA-2 at Harrow.

Based on the straight-line distance between the two sites and locally-measured wind speeds, inter-site transport is expected to occur on the order of 7 to $9 \mathrm{~h}$. This provides a rough estimate for the timescale of SOA formation during the Harrow-to-Bear Creek period, during which SOA increases by a factor of $\sim 2.5$. For comparison, SOA in Mexico City outflow was observed to increase by a factor of $\sim 2$ within $\sim 3 \mathrm{~h}$ (Jimenez et al., 2009). However, SOA production in the Mexico City plume slowed considerably after this initial period, with aging to $\sim 6 \mathrm{~h}$ yielding a much smaller increase.

Although the estimates of photochemical age and transport time used here are only semiquantitative, they can be used to obtain an approximate picture of the aging process. As noted in Sect. 3.3, SOA formation in the Detroit/Windsor plume occurred at a comparable rate to that observed at ground sites in Mexico City over $\sim 6 \mathrm{~h}\left(10.1 \mu \mathrm{g} \mathrm{m}^{-3} \mathrm{ppmv}^{-1} \mathrm{~h}^{-1}\right.$ for Detroit vs. $10.5 \mu \mathrm{g} \mathrm{m}^{-3} \mathrm{ppmv}^{-1} \mathrm{~h}^{-1}$ for Mexico City). Assuming $\sim 8 \mathrm{~h}$ for transport between Harrow and Bear Creek, the Harrow-to-Bear Creek period yields an SOA production rate of $5.3 \mu \mathrm{g} \mathrm{m}^{-3} \mathrm{ppmv}^{-1} \mathrm{~h}^{-1}$. Such slowing of the SOA production rate is consistent with the slowing behavior observed in Mexico City, as the Detroit/Windsor plume is expected to contain fresher emissions than the airmass sampled during the Harrow-to-Bear Creek period. For the Bear Creek-toHarrow period, SOA formation has entirely stopped, yielding an SOA production rate of $-0.4 \mu \mathrm{g} \mathrm{m}^{-3} \mathrm{ppmv}^{-1} \mathrm{~h}^{-1}$.

This trend of decreasing SOA formation also extends to the individual OOA-1 and OOA-2 factors. The OOA1 production rates in the Detroit/Windsor and Mexico City $(\sim 6 \mathrm{~h}$ average) plumes are again in good agreement (4.3 and $4.2 \mu \mathrm{g} \mathrm{m}^{-3} \mathrm{ppmv}^{-1} \mathrm{hr}^{-1}$, respectively). This rate decreases to $2.4 \mu \mathrm{g} \mathrm{m}^{-3} \mathrm{ppmv}^{-1} \mathrm{~h}^{-1}$ for the Harrowto-Bear Creek period and to $0.6 \mu \mathrm{g} \mathrm{m}^{-3} \mathrm{ppmv}^{-1} \mathrm{~h}^{-1}$ for Bear Creek-to-Harrow. For OOA-2, the Detroit/Windsor plume is somewhat lower than $\sim 6 \mathrm{~h}$ Mexico City (4.1 vs. $6.3 \mu \mathrm{g} \mathrm{m}^{-3} \mathrm{ppmv}^{-1} \mathrm{~h}^{-1}$ ). However, net OOA-2 production in Mexico City essentially ceases after $\sim 3 \mathrm{~h}$, while the Detroit/Windsor measurements are averaged over approximately 0 to $10 \mathrm{~h}$ of aging (see Fig. 7). The Harrowto-Bear Creek period yields a slower production rate, 3.3 $\mu \mathrm{g} \mathrm{m}^{-3} \mathrm{ppmv}^{-1} \mathrm{~h}^{-1}$ than either Detroit/Windsor or Mexico City. The Bear Creek-to-Harrow period shows decreasing OOA-2, with a production rate of $-1.5 \mu \mathrm{g} \mathrm{m}^{-3} \mathrm{ppmv}^{-1} \mathrm{~h}^{-1}$. This may suggest conversion of OOA-2 to OOA-1 and/or volatilization of OOA-2 oxidation products.

During the Detroit/Windsor outflow and Harrow-to-Bear Creek periods, the significant SOA formation and increases in the OOA-1 component emphasize the importance of highly oxidized, early-generation SOA products in polluted air. These rapid processes appear dominant on the approximately timescale investigated (up to $\sim 10 \mathrm{~h}$ ). However, this timescale is too short to rule out important contributions to SOA from aging processes acting over multiple days.

\section{Conclusions}

ToF-AMS instruments were deployed at two sites in southwestern Ontario during the BAQS-Met sampling campaign in summer 2007. PMF analysis was performed on a single dataset containing the mass spectral time series from both instruments. This is the first application of PMF to simultaneous AMS measurements at different sites; the method provides for self-consistent, direct comparison of the datasets. The PMF analysis yielded factors related to secondary oxidation processes (OOA-1, OOA-2) and primary emissions (HOA), as well as a factor tentatively attributed to the reactive uptake of isoprene uptake and/or its earlygeneration reaction products (UNKN). Case study periods were identified to study processing of (1) an urban plume 
(i.e. Detroit/Windsor outflow) and (2) regional aerosol during periods of inter-site transport. Regional aerosol processing was evaluated by comparison of AMS measurements performed simultaneously at two different sites during periods of inter-site transport. In the Detroit/Windsor outflow, SOA production was observed as a function of photochemical age as represented by the $\mathrm{NO}_{\mathrm{x}} / \mathrm{NO}_{\mathrm{y}}$ ratio. In contrast, the regional aerosol did not exhibit a strong correlation between SOA and $\mathrm{NO}_{\mathrm{x}} / \mathrm{NO}_{\mathrm{y}}$ at either site. However, evidence for continued atmospheric processing of regional SOA was observed by comparison of CO-normalized SOA concentrations at the two sites during periods of inter-site transport. Similar to previous measurements, the formation rate of SOA and SOA components decreased with airmass age. Rapid production $\left(10.1 \mu \mathrm{g} \mathrm{m}^{-3} \mathrm{ppmv}_{\mathrm{CO}}^{-1} \mathrm{~h}^{-1}\right)$ was observed in Detroit/Windsor outflow, with reduced or near-zero values obtained from older airmasses.

\section{Supplementary material related to this article is available online at: http://www.atmos-chem-phys.net/11/2991/2011/ acp-11-2991-2011-supplement.pdf.}

Acknowledgements. The authors gratefully acknowledge the NOAA Air Resources Laboratory (ARL) for the provision of the HYSPLIT transport and dispersion model. High-resolution back trajectories were provided by Qian Li (Environment Canada and Meteorological Service of Canada). Partial operational funding was provided by the Natural Sciences and Engineering Council of Canada (NSERC). This project has also received funding support from the Ontario Ministry of the Environment. Such support does not indicate endorsement by the Ministry of the contents of this material. Funding for SOCAAR was provided by the Canadian Foundation for Innovation, the Ontario Innovation Trust, and the Ontario Research Fund.

Edited by: R. McLaren

\section{References}

Aiken, A. C., DeCarlo, P. F., Kroll, J. H., Worsnop, D. R., Huffman, J. A., Docherty, K. S., Ulbrich, I. M., Mohr, C., Kimmel, J. R., Sueper, D., Sun, Y., Zhang, Q., Trimborn, A., Northway, M., Ziemann, P.J., Canagaratna, M. R., Onasch, T. B., Alfarra, M. R., Prevot, A. S. H., Dommen, J., Duplissy, J., Metzger, A., Baltensperger, U., and Jimenez, J. L.: O/C and OM/OC ratios of primary, secondary, and ambient organic aerosols with high-resolution time-of-flight aerosol mass spectrometry, Environ. Sci. Technol., 42, 4478-4485, 2008.

Albrecht, B. A.: Aerosols, cloud microphysics, and fractional cloudiness, Science, 245, 1227-1230, 1989.

Allan, J. D., Jimenez, J. L., Williams, P. I., Alfarra, M. R., Bower, K. N., Jayne, J. T., Coe, H., and Worsnop, D. R.: Quantitative sampling using an Aerodyne aerosol mass spectrometer 1: Techniques of data interpretation and error analysis, J. Geophys. Res., 108, 4090, doi:10.1029/2002JD002358, 2003.
Brown, S. S., Talukdar, R. K., and Ravishankara, A. R.: Rate constants for the reaction $\mathrm{OH}+\mathrm{NO}_{2}+\mathrm{M} \rightarrow \mathrm{HNO}_{3}+\mathrm{M}$ under atmospheric conditions, Chem. Phys. Lett., 229, 277-284, 1999.

Canagaratna, M. R., Jayne, J. T., Jimenez, J. L., Allan, J. D., Alfarra, M. R., Zhang, Q., Onasch, T. B., Drewnick, F., Coe, H., Middlebrook, A., Delia, A., Williams, L. R., Trimborn, A. M., Northway, M. J., DeCarlo, P. F., Kolb, C. E., Davidovits, P., and Worsnop, D. R.: Chemical and microphysical characterization of ambient aerosols with the Aerodyne aerosol mass spectrometer, Mass Spec. Rev., 26, 185-222, 2007.

Capes, G., Johnson, B., McFiggans, G., Williams, P. I., Haywood, J., and Coe, H.: Aging of biomass burning aerosols over West Africa: Aircraft measurements of chemical composition, microphysical properties, and emission ratios, J. Geophys. Res., 113, D00C15, doi:10.1029/2008JD009845, 2008.

Cross, E. S., Onasch, T. B., Canagaratna, M., Jayne, J. T., Kimmel, J., Yu, X.-Y., Alexander, M. L., Worsnop, D. R., and Davidovits, P.: Single particle characterization using a light scattering module coupled to a time-of-flight aerosol mass spectrometer, Atmos. Chem. Phys., 9, 7769-7793, doi:10.5194/acp-9-7769-2009, 2009.

D'Amours, R. and Pagé, P.: Atmospheric transport models for environmental emergencies, available at: http://collaboration.cmc.ec.gc.ca/cmc/cmoi/product_guide/ docs/lib/model-eco_urgences_e.pdf (last access: March 2011), 2001.

de Gouw, J. A. and Warneke, C.: Measurements of volatile organic compounds in the Earth's atmosphere using proton-transferreaction mass spectrometry, Mass Spec. Rev., 26, 223-257, 2007.

de Gouw, J. A., Middlebrook, A. M., Warneke, C., Goldan, P. D., Kuster, W. C., Roberts, J. M., Fehsenfeld, F. C., Worsnop, D. R., Canagaratna, M. R., Pszenny, A. A. P., Keene, W. C., Marchewka, M., Bertman, S. B., and Bates, T. S.: Budget of organic carbon in a polluted atmosphere: Results from the New England Air Quality Study in 2002, J. Geophys. Res., 110, D16305, doi:10.1029/2004JD005623, 2005.

de Gouw, J. A., Brock, C. A., Atlas, E. L., Bates, T. S., Fehsenfeld, F. C., Goldan, P. D., Holloway, J. S., Kuster, W. C., Lerner, B. M., Matthew, B. M., Middlebrook, A. M., Onasch, T. B., Peltier, R. E., Quinn, P. K., Senff, C. J., Stohl, A., Sullivan, A. P., Trainer, M., Warneke, C., Weber, R. L., and Williams, E. J.: Sources of particulate matter in the northeastern United States in summer: 1. Direct emissions and secondary formation of organic matter in urban plumes, J. Geophys. Res., 113, D08301, doi:10.1029/2007JD009243, 2008.

DeCarlo, P. F., Kimmel, J. R., Trimborn, A., Northway, M. J., Jayne, J. T., Aiken, A. C., Gonin, M., Fuhrer, K., Horvath, T., Docherty, K., Worsnop, D. R., and Jimenez, J. L.: A Field-deployable high-resolution time-of-flight aerosol mass spectrometer, Anal. Chem., 78, 8281-8289, 2006.

DeCarlo, P. F., Dunlea, E. J., Kimmel, J. R., Aiken, A. C., Sueper, D., Crounse, J., Wennberg, P. O., Emmons, L., Shinozuka, Y., Clarke, A., Zhou, J., Tomlinson, J., Collins, D. R., Knapp, D., Weinheimer, A. J., Montzka, D. D., Campos, T., and Jimenez, J. L.: Fast airborne aerosol size and chemistry measurements above Mexico City and Central Mexico during the MILAGRO campaign, Atmos. Chem. Phys., 8, 4027-4048, doi:10.5194/acp8-4027-2008, 2008. 
Draxler, R. R. and Rolph, G. D.: HYSPLIT (Hybrid Single-Particle Lagrangian Integrated Trajectory) Model access via NOAA ARL READY Website, available at: http://ready.arl.noaa.gov/ HYSPLIT.php, NOAA Air Resources Laboratory, Silver Spring, MD, 2010.

Drewnick, F., Hings, S. S., DeCarlo, P. F., Jayne, J. T., Gonin, M., Fuhrer, K., Weimer, S., Jimenez, J. L., Demerjian, K. L., Borrman, S., and Worsnop, D. R.: A new time-of-flight aerosol mass spectrometer (ToF-AMS) - Instrument description and first field deployment, Aerosol Sci. Technol., 39, 637-658, 2005.

Dzepina, K., Volkamer, R. M., Madronich, S., Tulet, P., Ulbrich, I. M., Zhang, Q., Cappa, C. D., Ziemann, P. J., and Jimenez, J. L.: Evaluation of recently-proposed secondary organic aerosol models for a case study in Mexico City, Atmos. Chem. Phys., 9, 5681-5709, doi:10.5194/acp-9-5681-2009, 2009.

Eidels-Dubovoi, S.: Aerosol Impacts on visible light extinction in the atmosphere of Mexico City, Sci. Tot. Environ., 287, 213-220, 2002.

Gamble, J.: $\mathrm{PM}_{2.5}$ and mortality in long-term prospective cohort studies: Cause-effect or statistical associations?, Environ. Health Perspectives, 106, 535-549, 1998.

Herndon, S. C., Onasch, T. B., Wood, E. C., Kroll, J. H., Canagaratna, M. R., Jayne, J. T., Zavala, M. A., Knighton, W. B., Mazzoleni, C., Dubey, M.,K., Ulbrich, I. M., Jimenez, J. L., Seila, R., de Gouw, J. A., de Foy, B., Fast, J., Molina, L. T., Kolb, C. E., and Worsnop, D. R.: Correlation of secondary organic aerosol with odd oxygen in Mexico City, Geophys. Res. Lett., 35, L15804, doi:10.10292008GL034058, 2008.

Hudman, R. C., Murray, L. T., Jacob, D. J., Millet, D. B., Turquety, S., Wu S., Blake, D. R., Goldstein, A. H., Holloway, J., and Sachse, G. W.: Biogenic versus anthropogenic sources of CO in the United States, Geophys. Res. Let., 35, L04801, doi:10.1029/2007GL032393, 2008.

Jayne, J. T., Leard, D. C., Zhang, X., Davidovits, P., Smith, K. A., Kolb, C. E., and Worsnop, D. R.: Development of an aerosol mass spectrometer for size and composition analysis of submicron particles, Aerosol Sci. Technol., 33, 49-70, 2000.

Jimenez, J. L., Canagaratna, M. R., Donahue, N. M., Prevot, A. S. H., Zhang, Q., Kroll, J. H., DeCarlo, P. F., Allan, J. D., Coe, H., Ng, N. L., Aiken, A. C., Docherty, K. D., Ulbrich, I. M., Grieshop, A. P., Robinson, A. L., Duplissy, J., Smith, J. D., Wilson, K. R., Lanz, V. A., Hueglin, C., Sun, Y. L., Tian, J., Laaksonen, A., Raatikainen, T., Rautiainen, J., Vaattovaara, P., Ehn, M., Kulmala, M., Tomlinson, J. M., Collins, D. R., Cubison, M. J., Dunlea, E. J., Huffman, J. A., Onasch, T. B., Alfarra, M. R., Williams, P. I., Bower, K., Kondo, Y., Schneider, J., Drewnick, F., Borrmann, S., Weimer, S., Demerjian, K., Salcedo, D., Cottrell, L., Griffin, R., Takami, A., Miyoshi, T., Hatakeyama, S., Shimono, A., Sun, J. Y., Zhang, Y. M., Dzepina, K., Kimmel, J. R., Sueper, D., Jayne, J. T., Herndon, S. C., Trimborn, A. M., Williams, L. R., Wood, E. C., Kolb, C. E., Middlebrook, A. M., Baltensperger, U., and Worsnop, D. R.: Evolution of organic aerosols in the atmosphere, Science, 326, 1525-1529, 2009.

Kleinman, L. I., Daum, P. H., Lee, Y.-N., Senum, G. I., Springston, S. R., Wang, J., Berkowitz, C., Hubbe, J., Zaveri, R. A., Brechtel, F. J., Jayne, J., Onasch, T. B., and Worsnop, D.: Aircraft observations of aerosol composition and ageing in New England and Mid-Atlantic States during the summer 2002 New England Air Quality Study field campaign, J. Geophys Res., 112, D09310,
doi:10.1029/2006JD007786, 2007.

Kleinman, L. I., Springston, S. R., Daum, P. H., Lee, Y.-N., Nunnermacker, L. J., Senum, G. I., Wang, J., Weinstein-Lloyd, J., Alexander, M. L., Hubbe, J., Ortega, J., Canagaratna, M. R., and Jayne, J.: The time evolution of aerosol composition over the Mexico City plateau, Atmos. Chem. Phys., 8, 1559-1575, doi:10.5194/acp-8-1559-2008, 2008.

Kleinman, L. I., Springston, S. R., Wang, J., Daum, P. H., Lee, Y.-N., Nunnermacker, L. J., Senum, G. I., Weinstein-Lloyd, J., Alexander, M. L., Hubbe, J., Ortega, J., Zaveri, R. A., Canagaratna, M. R., and Jayne, J.: The time evolution of aerosol size distribution over the Mexico City plateau, Atmos. Chem. Phys., 9, 4261-4278, doi:10.5194/acp-9-4261-2009, 2009.

Lanz, V. A., Alfarra, M. R., Baltensperger, U., Buchmann, B., Hueglin, C., and Prévôt, A. S. H.: Source apportionment of submicron organic aerosols at an urban site by factor analytical modelling of aerosol mass spectra, Atmos. Chem. Phys., 7, 1503-1522, doi:10.5194/acp-7-1503-2007, 2007.

Levy, I., Makar, P. A., Sills, D., Zhang, J., Hayden, K. L., Mihele, C., Narayan, J., Moran, M. D., Sjostedt, S., and Brook, J.: Unraveling the complex local-scale flows influencing ozone patterns in the southern Great Lakes of North America, Atmos. Chem. Phys., 10, 10895-10915, doi:10.5194/acp-10-10895-2010, 2010.

Li, Q., Jacob, D. J., Munger, W., Yantosca, R. M., and Parrish, D. D.: Export of $\mathrm{NO}_{\mathrm{y}}$ from the North American boundary layer, Reconciling aircraft measurements with global model budgets, J. Geophys. Res., 109, D02313, doi:10.1029/2003JD004086, 2004.

Lindinger, W., Hansel, A., and Jordan, A.: Proton-transfer reaction mass spectrometry (PTR-MS): on-line monitoring of volatile organic compounds at pptv levels, Chem. Soc. Rev., 27, 347-354, 1998.

Markovic, M. Z., Hayden, K. L., Murphy, J. G., Makar, P. A., Ellis, R. A., Chang, R. Y.-W., Slowik, J. G., Mihele, C., and Brook, J.: The effect of meteorological and chemical factors on the agreement between observations and predictions of fine aerosol composition in Southwestern Ontario during BAQS-Met, Atmos. Chem. Phys. Discuss., 10, 24781-24820, doi:10.5194/acpd-1024781-2010, 2010.

McLaren, R., Gertler, A. W., Wittorff, D. N., Belzer, W., Dann, T., and Singleton, D. L.: Real-world measurements of exhaust and evaporative emissions in the cassiar tunnel predicted by chemical mass balance modeling, Environ. Sci. Technol., 30, 3001-3009, 1996a.

McLaren, R., Singleton, D. L., Lai, J. Y. K., Khouw, B., Singer, E., $\mathrm{Wu}, \mathrm{Z}$., and Niki, H.: Analysis of motor vehicle sources and their contribution to ambient hydrocarbon distributions at urban sites in Toronto during the southern Ontario oxidants study, Atmos. Environ., 30, 2219-2232, 1996b.

Miller, S. M., Matross, D. M., Andrews, A. E., Millet, D. B., Longo, M., Gottlieb, E. W., Hirsch, A. I., Gerbig, C., Lin, J. C., Daube, B. C., Hudman, R. C., Dias, P. L. S., Chow, V. Y., and Wofsy, S. C.: Sources of carbon monoxide and formaldehyde in North America determined from high-resolution atmospheric data, Atmos. Chem. Phys., 8, 7673-7696, doi:10.5194/acp-8-7673-2008, 2008.

Morgan, W. T., Allan, J. D., Bower, K. N., Highwood, E. J., Liu, D., McMeeking, G. R., Northway, M. J., Williams, P. I., Krejci, R., and Coe, H.: Airborne measurements of the spatial distribution of aerosol chemical composition across Europe and evolu- 
tion of the organic fraction, Atmos. Chem. Phys., 10, 4065-4083, doi:10.5194/acp-10-4065-2010, 2010.

Ng, N. L., Canagaratna, M. R., Zhang, Q., Jimenez, J. L., Tian, J., Ulbrich, I. M., Kroll, J. H., Docherty, K. S., Chhabra, P. S., Bahreini, R., Murphy, S. M., Seinfeld, J. H., Hildebrandt, L., Donahue, N. M., DeCarlo, P. F., Lanz, V. A., Prévôt, A. S. H., Dinar, E., Rudich, Y., and Worsnop, D. R.: Organic aerosol components observed in Northern Hemispheric datasets from Aerosol Mass Spectrometry, Atmos. Chem. Phys., 10, 46254641, doi:10.5194/acp-10-4625-2010, 2010.

Paatero, P.: Least squares formulation of robust non-negative factor analysis, Chemom. Intell. Lab. Syst., 37, 23-35, 1997.

Paatero, P., and Tapper, U.: Positive matrix factorization: A nonnegative factor model with optimal utilization of error estimates of data values, Environmetrics, 5, 111-126, 1994.

Parrish, D. D., Ryerson, T. B., Holloway, J. S., Neuman, J. A., Roberts, J. M., Williams, J., Stroud, C. A., Frost, G. J., Trainer, M., Hubler, G., Fehsenfeld, F. C., Flocke, F., and Weinheimer, A. J.: Fraction and composition of $\mathrm{NO}_{\mathrm{y}}$ transported in air masses lofted from the North American continental boundary layer, J. Geophys. Res., 109, D09302, doi:10.1029/2003JD004086, 2004.

Peters, A., Dockery, D. W., Heinrich, J., and Wichman, H. E.: Short-term effects of particulate air pollution on respiratory morbidity in asthmatic children, Euro. Respir. J., 10, 872-879, 1997.

Pope, C. A. and Dockery, D. W.: Health effects of fine particulate air pollution: Lines that connect, J. Air Waste Manage. Assoc., 56, 709-742, 2006.

Pryor, S. C., Simpson, R., GuiseBagley, L., Hoff, R., and Sakiyama, S.: Visibility and aerosol composition in the Fraser Valley during REVEAL, J. Air Waste Manage. Assoc., 47, 147-156, 1997.

Roberts, J., Fehsenfeld, F., Liu, S., Bollinger, M., Hahn, C., Albritton, D., and Sievers, R.: Measurements of aromatic hydrocarbon ratios and $\mathrm{NO}_{\mathrm{x}}$ concentrations in the rural troposphere: observations of air mass photochemical aging and $\mathrm{NO}_{\mathrm{x}}$ removal, Atmos. Environ., 18, 2421-2432, 1984.

Robinson, A. L., Donahue, N. M., Shrivastava, M. K., Weitkamp, E. A., Sage, A. M., Grieshop, A. P., Lane, T. E., Pierce, J. R., and Pandis, S. N.: Rethinking organic aerosols: Semivolatile emissions and photochemical aging, Science, 315, 1259-1262, 2007.

Robinson, N. H., Hamilton, J. F., Allan, J. D., Langford, B., Oram, D. E., Chen, Q., Docherty, K., Farmer, D. K., Jimenez, J. L., Ward, M. W., Hewitt, C. N., Barley, M. H., Jenkin, M. E., Rickard, A. R., Martin, S. T., McFiggans, G., and Coe, H.: Evidence for a significant proportion of Secondary Organic Aerosol from isoprene above a maritime tropical forest, Atmos. Chem. Phys., 11, 1039-1050, doi:10.5194/acp-11-1039-2011, 2011.

Rolph, G. D.: Real-time Environmental Applications and Display sYstem (READY) Website, available at: http://ready.arl.noaa. gov, NOAA Air Resources Laboratory, Silver Spring, MD, 2010.

Siegl, W. O., McCabe, R. W., Chun, W., Kaiser, E. W., Perry, J., Henig, Y. I., Trinker, F. H., and Anderson, R. W.: Speciated hydrocarbon emissions from the combustion of single component fuels, I. Effect of fuel structure, J. Air Waste Manage. Assoc., 42, 912-920, 1992.
Sjostedt, S. J., Slowik, J. G., Brook, J. R., Chang, R.Y.-W., Mihele, C., Stroud, C. A., Vlasenko, A., and Abbatt, J. P. D.: Diurnally resolved particulate and VOC measurements at a rural site: indication of significant biogenic secondary organic aerosol formation, Atmos. Chem. Phys. Discuss., 10, 27321 27359, doi:10.5194/acpd-10-27321-2010, 2010.

Slowik, J. G., Stroud, C., Bottenheim, J. W., Brickell, P. C., Chang, R. Y.-W., Liggio, J., Makar, P. A., Martin, R. V., Moran, M. D., Shantz, N. C., Sjostedt, S. J., van Donkelaar, A., Vlasenko, A., Wiebe, H. A., Xia, A. G., Zhang, J., Leaitch, W. R., and Abbatt, J. P. D.: Characterization of a large biogenic secondary organic aerosol event from eastern Canadian forests, Atmos. Chem. Phys., 10, 2825-2845, doi:10.5194/acp-10-2825-2010, 2010.

Stroud, C., Makar, P., Moran, M. D., Gong, W., Gong, S., Zhang, J., Mihele, C., Brook, J., Liu, P., Slowik, J. G., Abbatt, J. P. D., Sills, D., Li, Q.: Biogenic and anthropogenic contributions to organic aerosol in southern Ontario: Air quality modelling for the BAQSMet study, Atmos. Chem. Phys. Discuss., in preparation, 2010.

Sullivan, A. P., Peltier, R. E., Brock, C. A., de Gouw, J. A., Holloway, J. S., Warneke, C., Wollny, A. G., and Weber, R. J.: Airborne measurements of carbonaceous aerosol soluble in water over northeastern United States: Method development and an investigation into water-soluble organic carbon sources, J. Geophys. Res., 111, D23S46, doi:10.1029/2006JD007072, 2006.

Takegawa, N., Miyakawa, T., Kondo, Y., Blake, D. R., Kanaya, Y., Koike, M., Fukuda, M., Komazaki, Y., Miyazaki, Y., Shimono, A., and Takeuchi, T.: Evolution of submicron organic aerosol in polluted air exported from Tokyo, Geophys. Res. Lett., 33, L15814, doi:10.1029/2006GL025815, 2006.

Twomey, S. A., Peipgrass, M., and Wolfe, T.: An assessment of the impact of pollution on the global albedo, Tellus, 36B, 356-366, 1984.

Ulbrich, I. M., Canagaratna, M. R., Zhang, Q., Worsnop, D. R., and Jimenez, J. L.: Interpretation of organic components from Positive Matrix Factorization of aerosol mass spectrometric data, Atmos. Chem. Phys., 9, 2891-2918, doi:10.5194/acp-9-2891-2009, 2009.

Volkamer, R., Jimenez, J. L., Dzepina, K., Salcedo, D., SanMartini, F. M., Molina, L. T., Worsnop, D. R., and Molina, M. J.: Secondary organic aerosol formation from anthropogenic air pollution: Rapid and higher than expected, Geophys. Res. Lett., 33, L17811, doi:10.1029/2006GL026899, 2006.

Weber, R. J., Sullivan, A. P., Peltier, R. C., Russell, A., Yan, B., Zheng, M., de Gouw, J., Warneke, C., Brock, C., Holloway, J. S., Atlas, E. L., and Edgerton, E.: A study of secondary organic aerosol formation in the anthropogenicinfluenced southeastern United States, J. Geophys. Res., 112, D13302, doi:10.1029/2007JD008408, 2007.

Zhang, Q., Alfarra, M. R., Worsnop, D. R., Allan, J. D., Coe, H., Canagaratna, M. R., and Jimenez, J. L.: Deconvolution and quantification of hydrocarbon-like and oxygenated organic aerosols based on aerosol mass spectrometry, Environ. Sci. Technol., 39, 4938-4952, 2005. 